University of South Florida

DIGITAL COMMONS

Digital Commons @ University of

@ UNIVERSITY OF SOUTH FLORIDA

South Florida

USF Tampa Graduate Theses and Dissertations

USF Graduate Theses and Dissertations

$10-29-2015$

\title{
Embedded System Design of a Real-time Parking Guidance System
}

Omkar Dokur

University of South Florida, omkardokur@mail.usf.edu

Follow this and additional works at: https://digitalcommons.usf.edu/etd

Part of the Computer Engineering Commons, Computer Sciences Commons, and the Electrical and Computer Engineering Commons

\section{Scholar Commons Citation}

Dokur, Omkar, "Embedded System Design of a Real-time Parking Guidance System" (2015). USF Tampa Graduate Theses and Dissertations.

https://digitalcommons.usf.edu/etd/5939

This Thesis is brought to you for free and open access by the USF Graduate Theses and Dissertations at Digital Commons @ University of South Florida. It has been accepted for inclusion in USF Tampa Graduate Theses and Dissertations by an authorized administrator of Digital Commons @ University of South Florida. For more information, please contact digitalcommons@usf.edu. 


\title{
Embedded System Design of a Real-time Parking Guidance System
}

by

\author{
Omkar Dokur
}

\author{
A thesis submitted in partial fulfillment \\ of the requirements for the degree of \\ Master of Science in Electrical Engineering \\ Department of Electrical Engineering \\ College of Engineering \\ University of South Florida
}

Co-Major Professor: Wilfrido Moreno, Ph.D. Co-Major Professor: Srinivas Katkoori, Ph.D. Paris Wiley, Ph.D.

Date of Approval:

October 12, 2015

Keywords: Arduino, Ultrasonic sensor, Vehicle detection, Camera validation, Space availability Copyright (C) 2015, Omkar Dokur 


\section{DEDICATION}

To my loving family for their patience and support. 


\section{ACKNOWLEDGMENTS}

This work has been supported and funded by the Student Green Energy Fund (SGEF), Office of Sustainability (OoS) at USF. I would like to thank Center for Urban Transportation and Research (CUTR) and Parking and Transportation Services at USF for their help in this project. My sincere gratitude to Dr. Wilfrido Moreno, Dr. Srinivas Katkoori and Dr. Rangachar Kasturi for their advice and guidance. I am very thankful to CUTR and specifically to Dr. Pei-Sung Lin and Sara Hendricks for their tremendous help. I would also like to thank Dr. Paris Wiley for serving on my thesis committee. I thank my project partners Rajmadhan Ekambaram and Noureddine Elmehraz for their

support. I would also like to thank my friends Janardhan Bhima Reddy Karri and Robert O'Brien for their assistance. 


\section{TABLE OF CONTENTS}

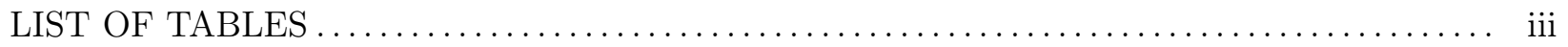

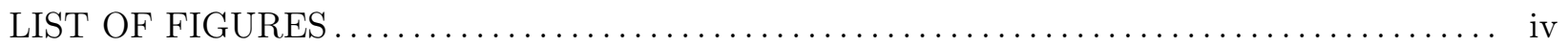

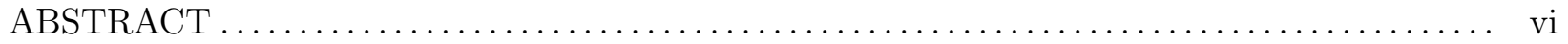

CHAPTER $1:$ INTRODUCTION AND MOTIVATION $\ldots \ldots \ldots \ldots \ldots \ldots \ldots \ldots \ldots \ldots \ldots \ldots$

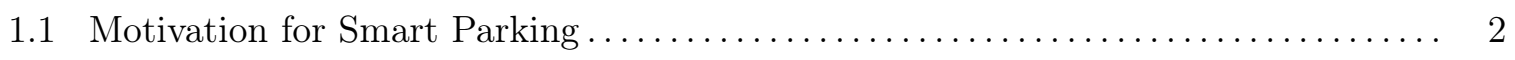

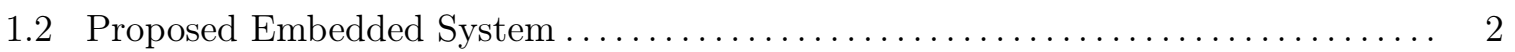

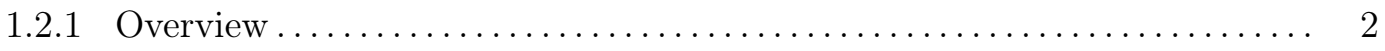

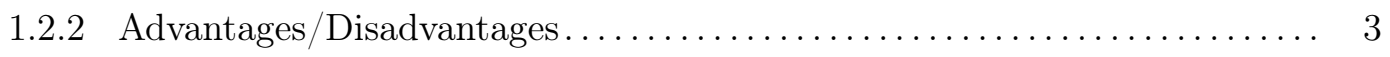

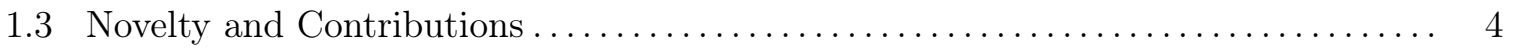

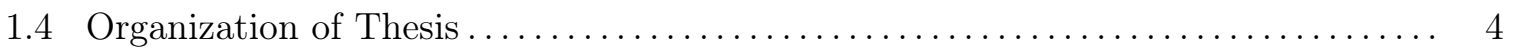

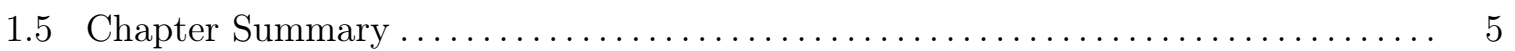

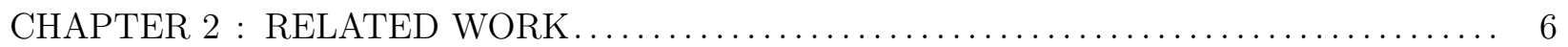

2.1 Study of Existing Vehicle Detection Sensor Technologies.................... 6

2.2 Comparison of Existing Systems with the Proposed System $\ldots \ldots \ldots \ldots \ldots \ldots \ldots \ldots$

2.3 Commercial Systems Considered by CUTR......................... 10

2.4 Chapter Summary ............................................ 13

CHAPTER 3 : PROPOSED PARKING GUIDANCE SYSTEM ................... 14

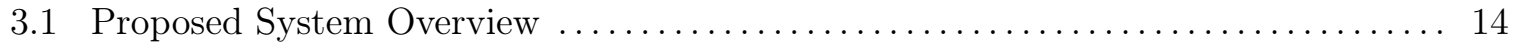

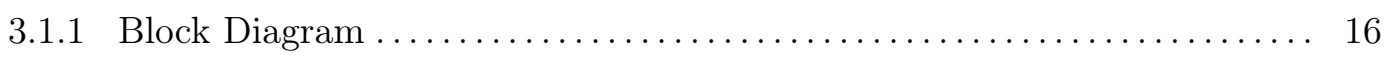

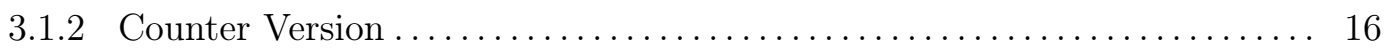

3.1 .3 Triggering Camera.................................. 17

3.2 Research of Sensor Technologies.................................. 18

3.2 .1 Visual Sensors ......................................... 18

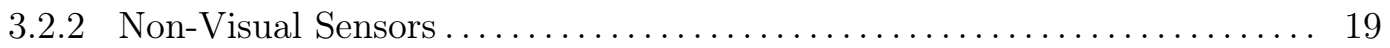

3.3 Vehicle Detection by Ultrasonic Sensor ........................... 20

3.4 Arduino Microcontroller Board ............................... 22

3.5 Vehicle Detection Logic .................................... 23

3.5.1 Vehicle Detection and Count.......................... 24 


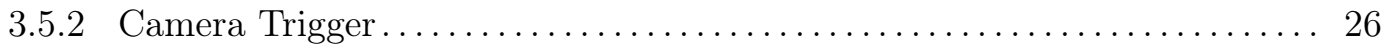

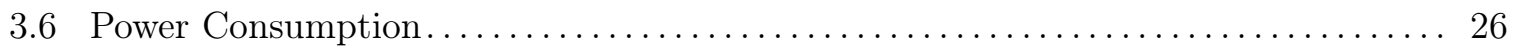

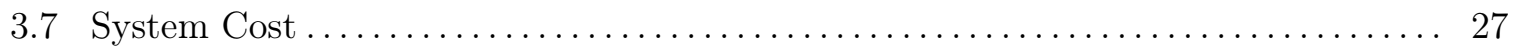

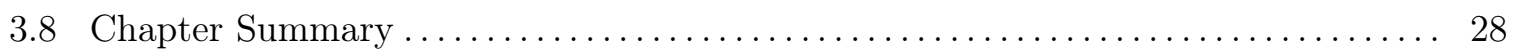

CHAPTER $4:$ EXPERIMENTAL RESULTS ............................ 29

4.1 Experimental Setup ............................................ 29

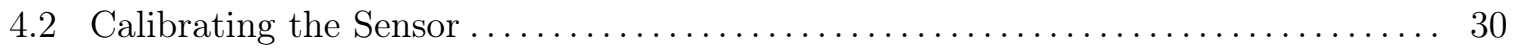

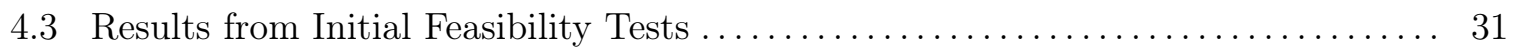

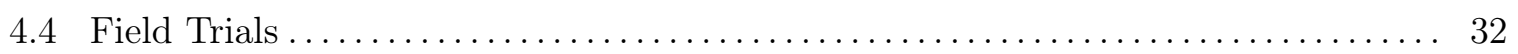

4.4 .1 Hourly and Peak Hour Times ............................. 40

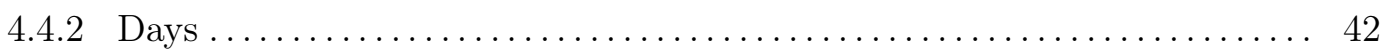

4.5 Chapter Summary ............................................... 42

CHAPTER $5:$ CONCLUSION AND FUTURE WORK $\ldots \ldots \ldots \ldots \ldots \ldots \ldots \ldots \ldots \ldots \ldots \ldots$

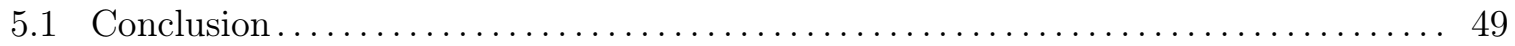

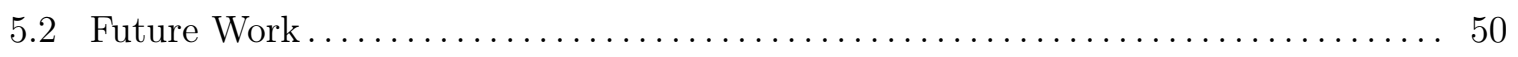

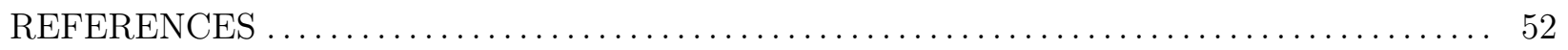

APPENDIX A: ARDUINO SOURCE CODE $\ldots \ldots \ldots \ldots \ldots \ldots \ldots \ldots \ldots \ldots \ldots \ldots \ldots \ldots \ldots$

APPENDIX B: ARDUINO COPYRIGHT NOTICE $\ldots \ldots \ldots \ldots \ldots \ldots \ldots \ldots \ldots \ldots \ldots \ldots \ldots$

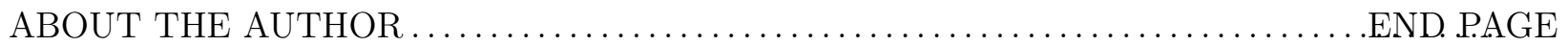




\section{LIST OF TABLES}

Table 2.1 Comparison of sensor technologies ............................ 8

Table 2.2 Advantages and disadvantages of sensor technologies.................. 9

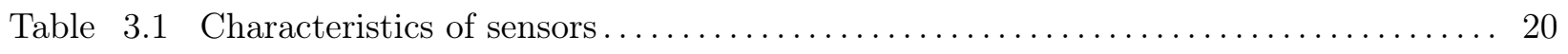

Table 3.2 Comparison of sensors considered for vehicle detection ................... 21

Table 3.3 Current consumption of the components used in the system $\ldots \ldots \ldots \ldots \ldots \ldots \ldots 27$

Table 3.4 Cost of the components used in the system $\ldots \ldots \ldots \ldots \ldots \ldots \ldots \ldots \ldots \ldots \ldots .27$

Table 3.5 Cost of different features of the system $\ldots \ldots \ldots \ldots \ldots \ldots \ldots \ldots \ldots \ldots \ldots \ldots \ldots \ldots$

Table 4.1 Day 1 - April 15 to April 16, 2015............................. 35

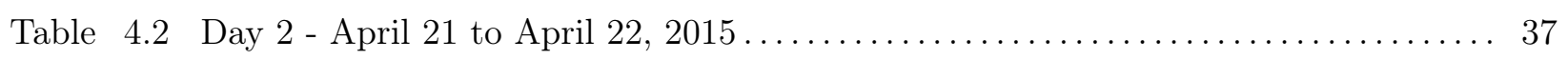

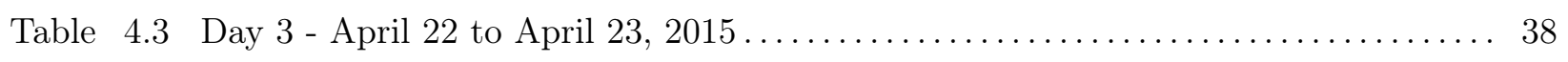

Table 4.4 Day 4 - April 23 to April $24,2015 \ldots \ldots \ldots \ldots \ldots \ldots \ldots \ldots \ldots \ldots \ldots \ldots \ldots \ldots . \ldots \ldots$

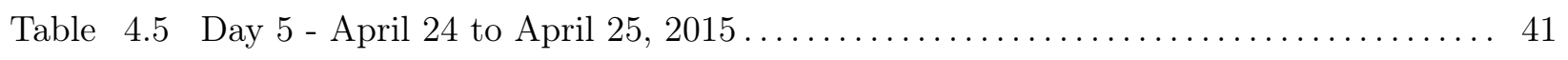

Table 4.6 Day 1 (accumulated) - April 15 to April 16, 2015 ................... 43

Table 4.7 Day 2 (accumulated) - April 21 to April $22,2015 \ldots \ldots \ldots \ldots \ldots \ldots \ldots \ldots \ldots \ldots 44$

Table 4.8 Day 3 (accumulated)- April 22 to April $23,2015 \ldots \ldots \ldots \ldots \ldots \ldots \ldots \ldots \ldots$

Table 4.9 Day 4 (accumulated) - April 23 to April 24, $2015 \ldots \ldots \ldots \ldots \ldots \ldots \ldots \ldots \ldots$

Table 4.10 Day 5 (accumulated) - April 24 to April $25,2015 \ldots \ldots \ldots \ldots \ldots \ldots \ldots \ldots \ldots . \ldots 7$

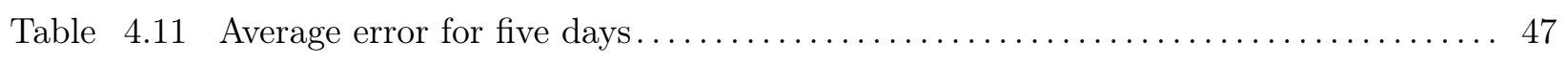

Table 4.12 Average error accumulated for five days $\ldots \ldots \ldots \ldots \ldots \ldots \ldots \ldots \ldots \ldots \ldots \ldots$ 


\section{LIST OF FIGURES}

Figure 1.1 Preliminary $\mathrm{CO}_{2}$ estimation by CUTR $\ldots \ldots \ldots \ldots \ldots \ldots \ldots \ldots \ldots \ldots \ldots$

Figure 3.1 Recognition of decal type ................................. 15

Figure 3.2 Real time parking information to drivers........................... 15

Figure 3.3 System block diagram $\ldots \ldots \ldots \ldots \ldots \ldots \ldots \ldots \ldots \ldots \ldots \ldots \ldots \ldots \ldots \ldots \ldots \ldots$

Figure 3.4 I/O pins of Axis Q1614 (Source: $[1]) \ldots \ldots \ldots \ldots \ldots \ldots \ldots \ldots \ldots \ldots \ldots \ldots \ldots \ldots$

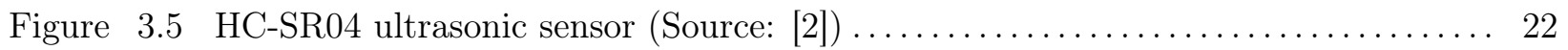

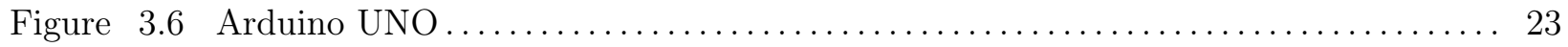

Figure 3.7 Flow chart of the logic to count the number of vehicles $\ldots \ldots \ldots \ldots \ldots \ldots \ldots \ldots$

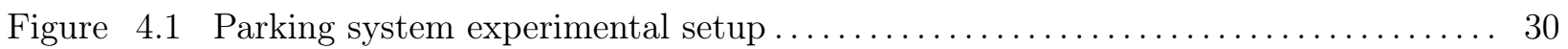

Figure 4.2 Plot of distances of slow moving vehicles $(5 \mathrm{mph}) \ldots \ldots \ldots \ldots \ldots \ldots \ldots \ldots \ldots \ldots \ldots$

Figure 4.3 Plot of distances of fast moving vehicles $(20 \mathrm{mph}) \ldots \ldots \ldots \ldots \ldots \ldots \ldots \ldots \ldots \ldots$

Figure 4.4 System installation at West entrance of Richard Beard Garage ............... 33

Figure 4.5 Example of a golf cart entering the garage $\ldots \ldots \ldots \ldots \ldots \ldots \ldots \ldots \ldots \ldots \ldots \ldots$

Figure 4.6 Example of cars exiting from the garage $\ldots \ldots \ldots \ldots \ldots \ldots \ldots \ldots \ldots \ldots \ldots \ldots \ldots \ldots \ldots \ldots \ldots \ldots$

Figure 4.7 Example of people walking under the sensor $\ldots \ldots \ldots \ldots \ldots \ldots \ldots \ldots \ldots \ldots \ldots$

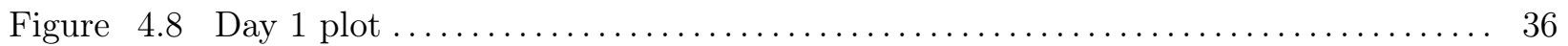

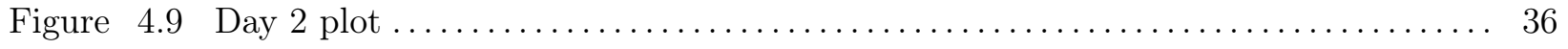

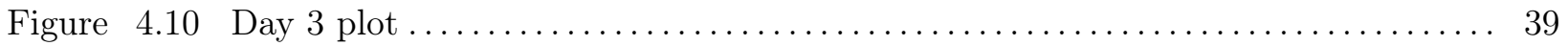

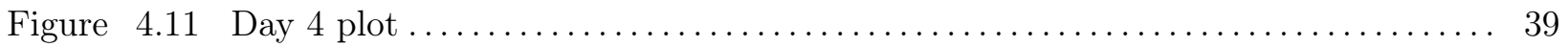




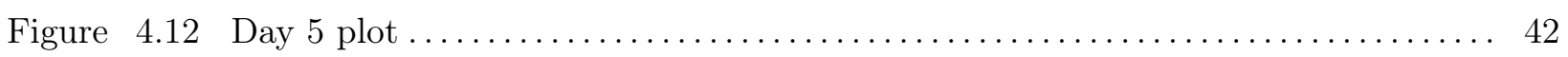

Figure 5.1 Flowchart of the logic to detect parking space availability ................ 50 


\begin{abstract}
The primary objective of this work is to design a parking guidance system to reliably detect entering/exiting vehicles to a parking garage in a cost-efficient manner. Existing solutions (inductive loops, RFID based systems, and video image processors) at shopping malls, universities, airports etc., are expensive due to high installation and maintenance costs. There is a need for a parking guidance system that is reliable, accurate, and cost-effective. The proposed parking guidance system is designed to optimize the use of parking spaces and to reduce wait times. Based on a literature review we identify that the ultrasonic sensor is suitable to detect an entering/exiting vehicle. Initial experiments were performed to test the sensor using an Arduino based embedded system. Detection logic was then developed to identify a car after analyzing the initial test results. This logic was extended to trigger a camera to take an image of the vehicle for validation purposes. This system consists of Arduino, ultrasonic sensor, and a temperature sensor. It was installed and tested in Richard Beard Garage at the University of South Florida for five days. The test results of each trial are provided and average error for all the trials is calculated. The error cases occur due to golf carts, straddling cars on both entry/exit lanes, and people walking under the sensor. The average error of the system is $5.36 \%$ over five days $(120 \mathrm{hrs})$. The estimated cost for one detector per lane is approximately $\$ 30$.
\end{abstract}




\section{CHAPTER 1 : INTRODUCTION AND MOTIVATION}

Parking a car is becoming a challenge to drivers. Drivers are frustrated while waiting for a long time in a queue or will just drive through the entire parking lot but still unable to find a parking spot [3]. While searching for a vacant parking spot, fuel is lost, and time is wasted; this also increases the traffic due to slow moving vehicles that are driving around the parking garage [3]. Further it contributes to green house gas emissions ( $\mathrm{CO}_{2}$ emissions). A study from Boston University states that more than $30 \%$ of the drivers take around 7.8 minutes to park their vehicle [4]. Parking spaces are necessary to park the vehicle, and the need is increasing day by day as there are more cars on the road than the number of parking spaces [5]. The only way to optimize the use of parking space and reduce the parking wait time is to install a proper parking guidance system. For this reason, University of South Florida (USF) Center for Urban Transportation and Research (CUTR) proposed a smart parking guidance system project to improve the parking experience for students, faculty, and visitors on campus. The project is funded by Student Green Energy Fund (SGEF). This thesis focuses on designing of an embedded system that detects vehicles when they enter/exit the parking garage. This system is part of an overall parking guidance system that can facilitate the drivers to know the available number of spaces in a parking lot/garage before entering via a smart phone app. 


\subsection{Motivation for Smart Parking}

The University of South Florida (USF) has four parking garages and eighty eight surface lots providing 20,000 parking spaces. However, students and faculty still find difficulty in parking their vehicles during rush hours leading to excess fuel consumption. The Center for Urban Transportation and Research (CUTR) surveyed (unpublished) three parking lots (CBG, 29A, 29B) at USF to estimate the average time taken by drivers to park their vehicle. On average, each student takes 3.76 minutes to park their vehicle in the above three garages which produces approximately 332 metric tons of $\mathrm{CO}_{2}$ emission annually into the campus environment. Fuel and time can be saved by informing users about the space availability well in advance. With a reliable parking guidance system, we can reduce the time taken by students to park and decrease $\mathrm{CO}_{2}$ emissions, thus protecting the

environment. According to the CUTR surveys, if the parking time is reduced by 2 minutes, the $\mathrm{CO}_{2}$ emissions would be reduced from the three garages to 155 metric tons ( $53 \%$ annual reduction). Figure 1.1 is the preliminary estimation done by CUTR. This primarily motivated us to research a parking guidance system that is reliable, efficient, and economical.

\subsection{Proposed Embedded System}

This section discusses the embedded system researched in this project. An overview of the embedded system is given. The advantages and disadvantages are also discussed.

\subsubsection{Overview}

The idea of using a ready made embedded platform led us to choose Arduino, an open source platform that has easy to use hardware and software. We selected Arduino UNO because of its 


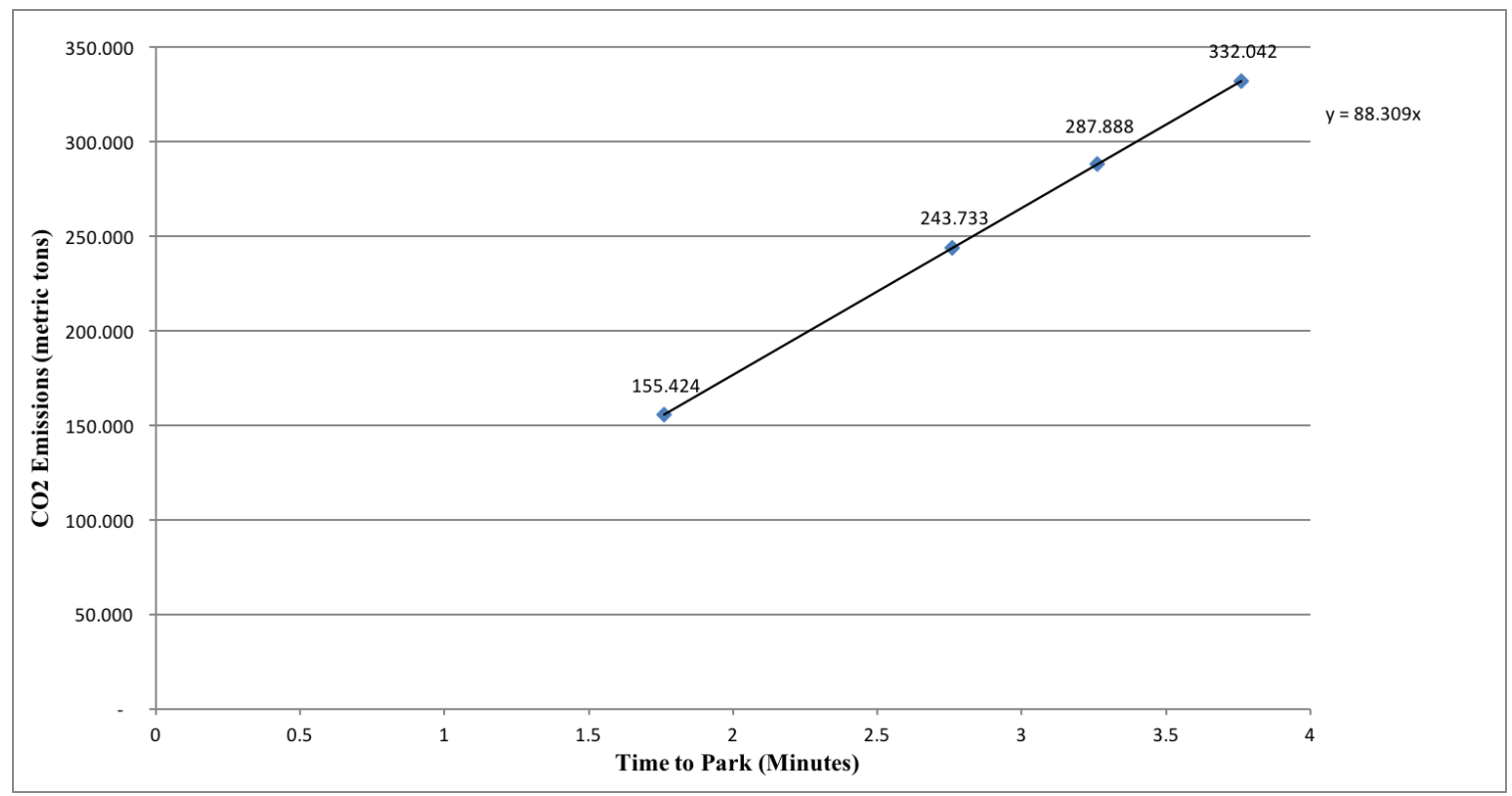

Figure 1.1: Preliminary $\mathrm{CO}_{2}$ estimation by CUTR

excellent features and low price. Ultrasonic sensor HC-SR04 is the sensor used for detecting vehicles. Temperature sensor TMP-36 is used to measure the temperature of the air.

\subsubsection{Advantages/Disadvantages}

This section lists the advantages and disadvantages of the proposed embedded system.

1. Advantages

- Consumes less power

- Easy to install in the garage

- Cost efficient

2. Disadvantages

- Detects people as a car 
- Detects golf cart as a car

These can be overcome by further extending the design as discussed in future work section.

\subsection{Novelty and Contributions}

The proposed parking guidance system presents a unique method of vehicle detection using an ultrasonic sensor. Although researchers have used ultrasonic sensor to detect empty parking spaces, to best of our knowledge, no prior researcher have used it to detect vehicles in motion. We also show the logic involved in detecting the vehicle using flowcharts. The system is cheaper than any other available parking technologies. We built a working prototype and demonstrated its efficacy in detecting vehicles reliably in an on-campus garage over 5 days. We survey extensively the possible sensors and compare them in detail. This is useful for future researchers working on this problem.

\subsection{Organization of Thesis}

The rest of the thesis is organized as follows. Chapter 2 presents a literature survey on sensor to detect a vehicle, discusses existing parking technologies and the commercial systems considered by CUTR. Chapter 3 describes the proposed vehicle detection system with the logic involved in identifying a vehicle. It also estimates the power consumption of the system, and cost of the system. Chapter 4 details the experimental set up used, and provides the initial experimental data collected for vehicle detection. It also reports and analyzes the data collected in a 5-day trial. Chapter 5 concludes the thesis and outlines the future work. 


\subsection{Chapter Summary}

In this chapter, the challenges involved in parking a vehicle in a high demand parking lot are explained. The motivation behind this project is also discussed. The overview of the embedded system is presented. 


\section{CHAPTER 2 : RELATED WORK}

We review existing vehicle detection sensor technologies and compare them with the proposed system. CUTR has considered a few commercial technologies to be installed at USF. We will also review these commercial systems.

\subsection{Study of Existing Vehicle Detection Sensor Technologies}

The existing systems use the following sensor technologies: 1) Active infrared sensor; 2) Passive infrared sensor; 3) Microwave radar; 4) Ultrasonic sensor; 5) Inductive loops; and 6) Radio frequency identification. Below we will briefly explain the operating principles of each technology.

1. Active Infrared Sensor: In active infrared sensors, a light emitting diode transmits infrared light and a photodiode receives the reflected light back [6]. Photodiode registers an object only if the path of the light is distorted. Here the transmitter, i.e., the permit, should be mounted on top of the windshield as the beam cannot penetrate the windshield. There is a possibility of theft of the tag if it is placed on the windshield of the car.

2. Passive Infrared Sensor (PIR): The passive infrared sensor works on the basis of ambient temperature. It detects incident infrared radiation that varies in proportion to the temperature difference between the vehicles and surrounding environment [7]. This sensor sends a pulse if the temperature difference is greater than $4^{\circ} \mathrm{C}$. The reliability of this sensor is questionable under dynamic weather conditions as dust, gases, or vapor can cause inaccuracies in measure- 
ment and may damage sensor lenses [8]. This sensor may detect person as a car which leads to unreliable parking count.

3. Microwave Radar: Microwave sensors are based on the Doppler Effect. The transmitter emits a radio wave on the surface of the object and a receiver embedded in the sensor receives the reflected wave. Using the frequency shift of the wave reflected from a moving surface, microwave sensors can calculate speed and distance of the object. Passive microwave sensors detect naturally emitted microwave energy within its field of view. All objects emit microwave energy of some magnitude, which is related to the temperature and moisture properties of the emitting object. These sensors are typically radiometers or scanners that use an antenna to detect and record the microwave energy [6]. These sensors can be affected by noise.

4. Ultrasonic Sensor: Most of the present technologies use an ultrasonic sensor to detect a vehicle $[5,9,10]$. Ultrasonic sensors transmit sound pulses to the ground and detect reflected pulses [6]. A sensor is used in each parking spot, and the status of each space is transmitted to the central control unit using Zigbee network configurations. This kind of a parking system requires installation of the sensor at each spot. Maintenance of Zigbee network configurations involves manpower and requires high installation costs.

5. Inductive Loops: Inductive loops detect metal objects using electromagnetic principle [11]. The system requires installation of sensors into the pavements at each entrance/exit to maintain the count of the vehicles, and at each spot for space indication. This requires massive amounts of labor if it is to be done on a large scale.

6. Radio Frequency Identification (RFID): RFID technology requires a tag for each vehicle and a reader where reader detects the tag $[6,8]$. The system needs drivers to drive their car under 
the reader. In this case, there are chances of the reader missing the tag. Moreover, the reader may not be able to detect a vehicle without a tag. All these factors can give an error in the aggregate count in the parking lot for this kind of system.

\subsection{Comparison of Existing Systems with the Proposed System}

Table 2.1 compares the proposed system with the existing systems. The current sensor technologies (active infrared, passive infrared, microwave, inductive loop, ultrasonic, and RFID) are compared with the proposed parking guidance system. The metrics considered for comparison are installation, maintenance, cost, and accuracy of the systems. These factors are examined to analyze the advantages and disadvantages of the existing parking technologies with the proposed parking guidance system (Table 2.2).

Table 2.1: Comparison of sensor technologies

\begin{tabular}{|c|c|c|c|c|}
\hline $\begin{array}{c}\text { Sensor } \\
\text { Technology }\end{array}$ & Installation & Maintenance & Cost & Accuracy \\
\hline $\begin{array}{c}\text { Active Infrared } \\
\text { Sensor }\end{array}$ & $\begin{array}{c}\text { Ceiling } \\
\text { Mount }\end{array}$ & Medium & Expensive & Accurate \\
\hline $\begin{array}{c}\text { Passive Infrared } \\
\text { Sensor (PIR) }\end{array}$ & $\begin{array}{c}\text { Ceiling } \\
\text { Mount }\end{array}$ & Low & Expensive & Unreliable \\
\hline $\begin{array}{c}\text { Microwave } \\
\text { Sensor }\end{array}$ & $\begin{array}{c}\text { Ceiling } \\
\text { Mount }\end{array}$ & Medium & Expensive & Accurate \\
\hline $\begin{array}{c}\text { Inductive } \\
\text { Loop }\end{array}$ & $\begin{array}{c}\text { Surface } \\
\text { Pavements/ } \\
\text { Ceiling }\end{array}$ & Low & Very & Highly \\
Sensor & Mount & & Expensive & Accurate \\
\hline Ultrasonic & Ceiling & Medium & Expensive & Accurate \\
Sensor & Mount & & Accurate in \\
\hline RFID & Ceiling & Medium & Expensive & Acontrolled situations \\
\hline $\begin{array}{c}\text { Proposed } \\
\text { System }\end{array}$ & Ceiling & Low & Economical & Accurate \\
\hline
\end{tabular}


As Table 2.2 indicates, inductive loops give high accuracy, but can be costly. RFID technology has high precision, but it detects only cars with tags. This may lead to an inaccurate count over time. Also, the price of readers is very expensive. The parking count with infrared and ultrasonic sensor technologies is estimated by installing these sensors in each space. Installing sensors for each space is costly and requires maintenance. Also, the PIR sensor is affected by climatic conditions and is unreliable. Microwave sensor technology gives an accurate count, but is very expensive. The proposed system is economical, requires low maintenance, easy to install and is accurate. The only disadvantage of the system is that it can incorrectly counts golf carts and peoples walking under the sensor as vehicles.

Table 2.2: Advantages and disadvantages of sensor technologies

\begin{tabular}{|c|c|c|}
\hline $\begin{array}{c}\text { Sensor } \\
\text { Technology }\end{array}$ & Advantages & Disadvantages \\
\hline $\begin{array}{l}\text { Active } \\
\text { Infrared } \\
\text { Sensor }\end{array}$ & $\begin{array}{l}\text { - Easy to mount receiver } \\
\text { on the ceiling } \\
\text { - Accurate }\end{array}$ & $\begin{array}{l}\text { - Permit tag to be mounted on top of wind shield } \\
\text { which may lead to theft of the tag } \\
\text { - Costly }\end{array}$ \\
\hline $\begin{array}{l}\text { Passive } \\
\text { Infrared } \\
\text { Sensor }\end{array}$ & $\begin{array}{l}\text { - Requires low } \\
\text { maintenance }\end{array}$ & $\begin{array}{l}\text { - May detect person as a car which } \\
\text { leads to unreliable parking count } \\
\text { - Costly }\end{array}$ \\
\hline $\begin{array}{l}\text { Microwave } \\
\text { Sensor }\end{array}$ & - Low maintenance & $\begin{array}{l}\text { - Affected by noise } \\
\text { - Can detect anything as a car }\end{array}$ \\
\hline $\begin{array}{l}\text { Inductive } \\
\text { Loop } \\
\text { Sensor }\end{array}$ & $\begin{array}{l}\text { - High Accuracy } \\
\text { - Low Maintenance }\end{array}$ & $\begin{array}{l}\text { - Surface installation may be too complex and } \\
\text { difficult to change once installed } \\
\text { - Very Expensive }\end{array}$ \\
\hline $\begin{array}{l}\text { Ultrasonic } \\
\text { Sensor }\end{array}$ & - High Accuracy & $\begin{array}{l}\text { - Requires installation in each space } \\
\text { - Very expensive }\end{array}$ \\
\hline RFID & - High Accuracy & $\begin{array}{l}\text { - Detects only cars with RFID tags } \\
\text { - Very expensive as four readers required } \\
\text { which costs up to } \$ 7,000 \text { each }\end{array}$ \\
\hline $\begin{array}{l}\text { Proposed } \\
\text { System }\end{array}$ & $\begin{array}{l}\text { - Economical } \\
\text { - Low Maintenance } \\
\text { - Easy to install } \\
\text { - Optimum Accuracy }\end{array}$ & $\begin{array}{l}\text { - Detects golf cart as a car } \\
\text { - Detects people as a car }\end{array}$ \\
\hline
\end{tabular}




\subsection{Commercial Systems Considered by CUTR}

The commercial systems considered by CUTR are: 1) Inductive loops; 2) Individual space sensors; 3) RFID; and 4) License plate recognition cameras. The hardware costs, maintenance, installation, advantages, and disadvantages of each system are discussed below.

\section{Inductive Loops}

This system includes installation of inductive loops (electro-magnetic sensors) into the pavements in surface lots or affixed to the ceiling in the garages and gives an aggregate count of the vehicles entering/exiting the garage. Hardware costs are around $\$ 10,000-\$ 15,000$ per entrance/exit. It has low maintenance and minimal monitoring software costs. It is a tried and tested technology and can give the accurate aggregate count. CASE Systems and TCS International are the vendors offering this technology. The advantages of this system are:
(a) High accuracy
(b) Low maintenance, and
(c) Minimal monitoring and software costs

The disadvantages of the system are:

(a) High cost

(b) Low flexibility

\section{Individual Space Sensors}

Each space in the garage is equipped with an individual space sensor. Electromagnetic sensor technology is used which can be cut into pavements or affixed to the ceiling. This system 
is very expensive and costs $\$ 200$ - $\$ 250$ per parking space. It has a high level of accuracy and requires minimal monitoring software costs. Streetline, Inc. offers this technology. The advantages of this system are:
(a) High accuracy
(b) Low maintenance, and
(c) Minimal monitoring and software costs

The disadvantages of the system are:

(a) High cost if installation in garages is widespread

(b) Alteration in infrastructure needed if space designations are changed

\section{RFID}

In this technology, a microchip is embedded into permit types and the RFID reader identifies the permit of the vehicles entering/exiting the garage. The reader is mounted on the ceiling of the garage or near to entrance/exit. To ensure accurate vehicle count, lane dividers are required to determine the direction of the traffic. The permit costs $\$ 15-\$ 20$ and $\$ 7,000$ per reader. It has high accuracy in only controlled situations. TransCore offers RFID smart parking system. The advantages of this system are:

(a) High level of accuracy when lane dividers are used

(b) Readers can be installed in any parking lot

The disadvantages of the system are:

(a) Cannot detect vehicles without a permit 
(b) More chances of reader missing the tag, and

(c) High cost as it requires at least four readers for a garage

\section{License Plate Recognition (LPR) Cameras}

Infrared digital cameras and dedicated software are used in license plate recognition to detect and read the letters on car's license plate. The detected license number is compared with stored license plate number registered with the institution to determine the permit type related to the vehicle. AutoVu is the dedicated software used and requires a minimum of two cameras per entrance/exit installed above the entrances/exits where the cost of each camera is $\$ 10,000$. The cameras need a direct line of sight to maintain an accurate count. Genetec offers this technology. The advantages of this system are:

(a) Gives $93 \%$ - $95 \%$ of accuracy

(b) AutoVu is adaptable with the USF server applications

The disadvantages of the system are:

(a) Adaption of new software includes additional costs

(b) Using cameras may raise privacy issues

(c) Very expensive as minimum of two cameras required per entrance/exit, and

(d) Cannot read the license plate number if there is no line of sight

After analyzing the present technologies, further study was conducted to find an economical sensor, that would be most reliable, efficient, and accurate. 


\subsection{Chapter Summary}

This chapter discussed existing vehicle detection sensor technologies. Characteristics of these sensors are discussed and are compared to better understand their behavior. In summary, several technologies have trade-offs in terms of accuracy, cost, and installation. 


\section{CHAPTER 3 : PROPOSED PARKING GUIDANCE SYSTEM}

We present in detail the proposed parking guidance system based on ultrasonic sensor and Arduino.

We will describe the design flow used to arrive at the proposed system configuration. Briefly the tasks are:

1. Determination of sensor

2. Initial trials to consolidate detection logic

3. System prototyping, and

4. Cost and power analysis

\subsection{Proposed System Overview}

The overall system detects a car entering the garage and triggers a camera to capture an image of the windshield as shown in Figure 3.1. The image is used to identify the type of vehicle decal and therefore to count vehicles by permit type. After determining the decal type, parking count is updated in real-time on the server as shown in Figure 3.2. The parking count is accessible to the drivers through a smart phone app.

The proposed embedded system detects a vehicle, triggers the camera to capture images and maintains the count of the vehicles. The system uses an ultrasonic sensor, an Arduino microcontroller board, and a temperature sensor. The system maintains the count of the vehicles, which provides the number of parking spots available in the parking lot. Also, a camera is triggered to take 2-5 


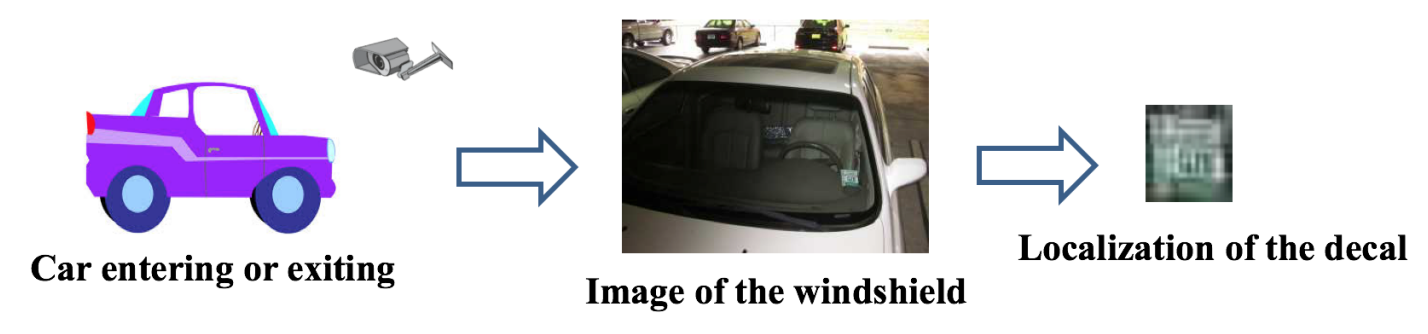
$S-200$
$\mathrm{R}-150$
$\mathrm{Y}-25$
$\mathrm{E}-75$
$\mathrm{G} Z-10$

Reserved - 5

Permit types count

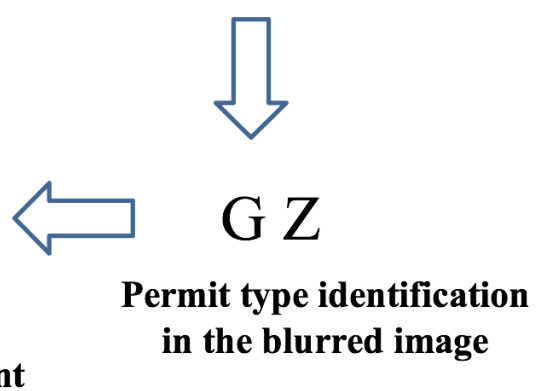

Figure 3.1: Recognition of decal type

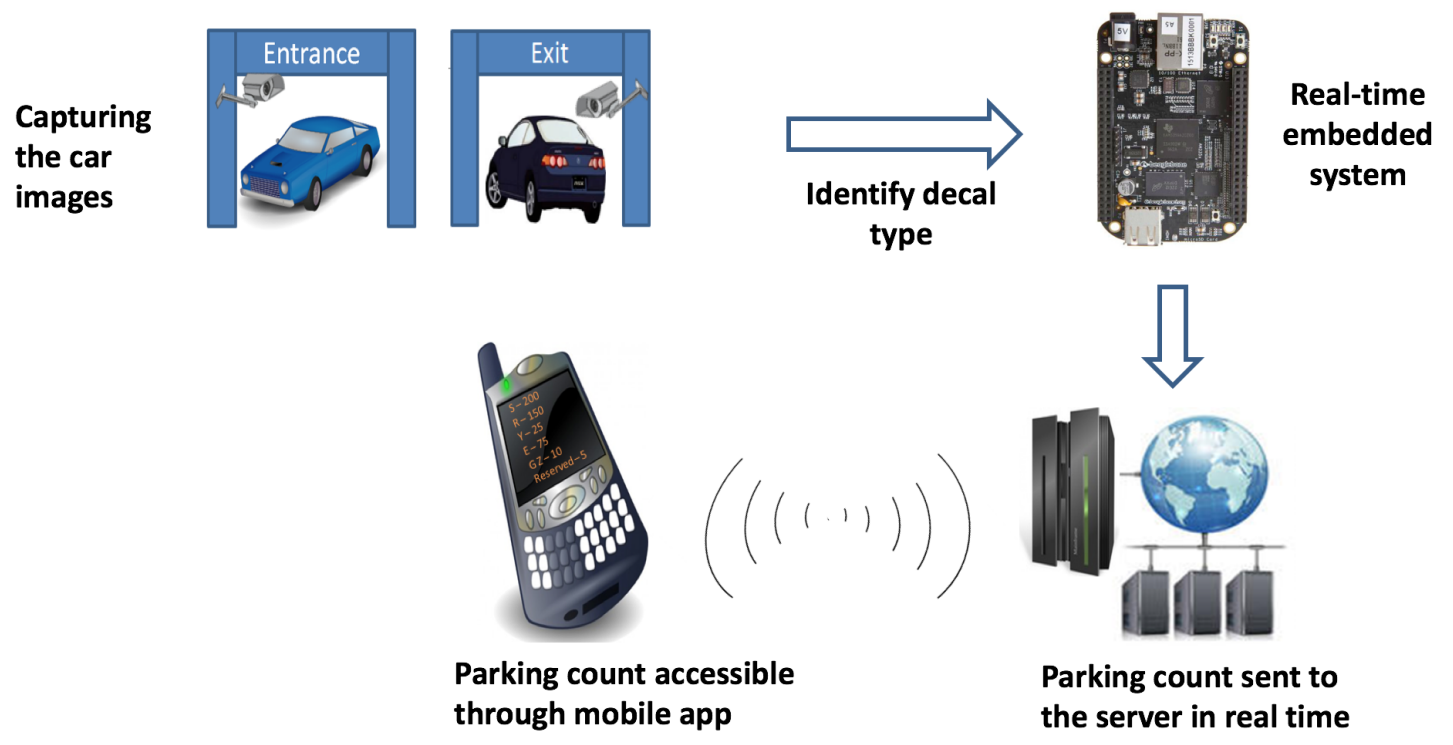

Figure 3.2: Real time parking information to drivers

images the moment a vehicle is detected. These images were used for further research and also to verify the system's efficiency. The two versions of the system are: counter version which maintains 
the overall count of the garage and, trigger version which triggers camera for decal recognition. This thesis reports the counter version.

\subsubsection{Block Diagram}

Figure 3.3 shows the block diagram of the parking guidance system. Arduino Uno, ultrasonic sensor, and temperature sensor are used to build the system. Ultrasonic sensor works on the principle of sound waves and the speed of sound is sensitive to air temperature. Temperature sensors estimates the speed of sound which removes the error due to changing weather conditions. First, ultrasonic and temperature sensors are connected to the Arduino microcontroller. The controller detects the vehicle by triggering the sensor, and then it counts the vehicle and triggers the camera to send images to the web server.

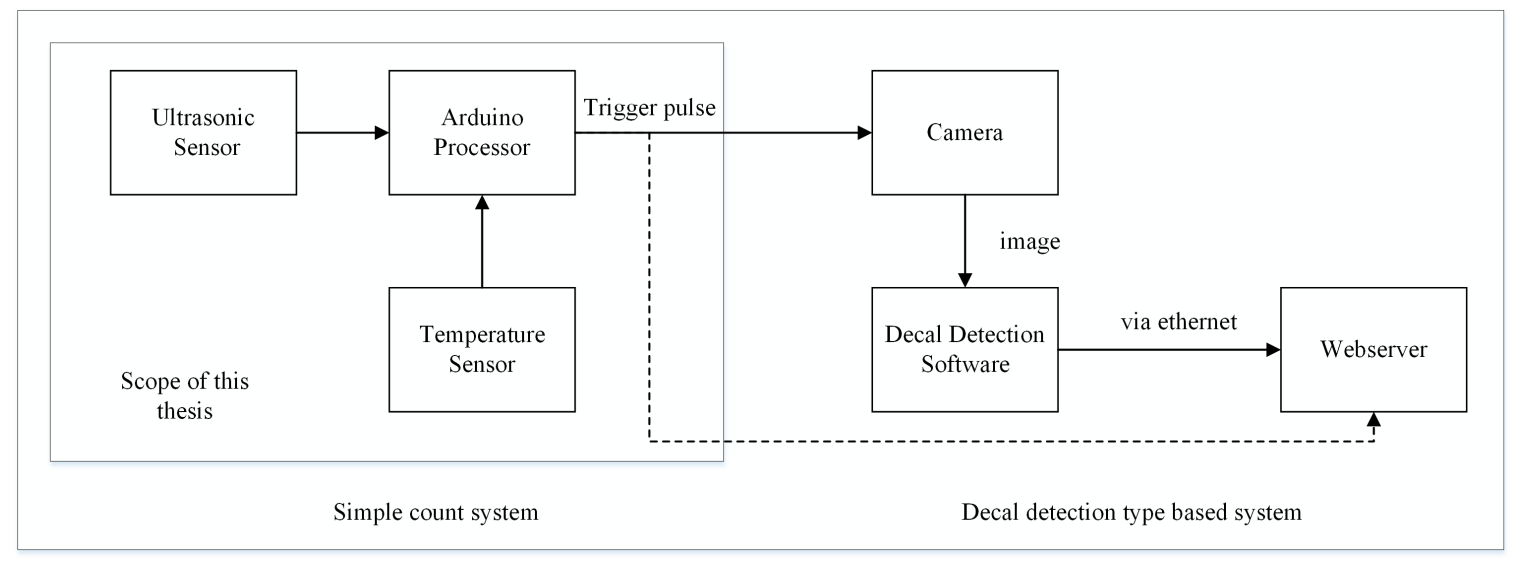

Figure 3.3: System block diagram

\subsubsection{Counter Version}

The working model of a counter version is shown as simple count system in Figure 3.3. Here, the microcontroller checks for obstacle by triggering the ultrasonic sensor. Whenever an obstacle is 
detected, the controller determines if the obstacle is a vehicle or not by triggering more pulses. The logic involved in vehicle detection and count is thoroughly explained in Section 3.5. Once the vehicle is detected, the web server is updated with increment/decrement in the number according to entry/exit as shown in dotted lines. For the overall count of the parking lot, this kind of system is installed at each entry and exit and is integrated with the web server. The web server calculates the overall count by subtracting the number of vehicles exited from the number of vehicles entered.

\subsubsection{Triggering Camera}

The parking guidance system is designed to trigger an external camera to take a video/image when a vehicle is detected. Axis Q1614, a network camera is used in this system. It has four I/O ports as shown in Figure 3.4, in which one of them is trigger input. Once the processor detects a vehicle, it sends a pulse to the camera through the $\mathrm{I} / \mathrm{O}$ pin 3 of the camera.

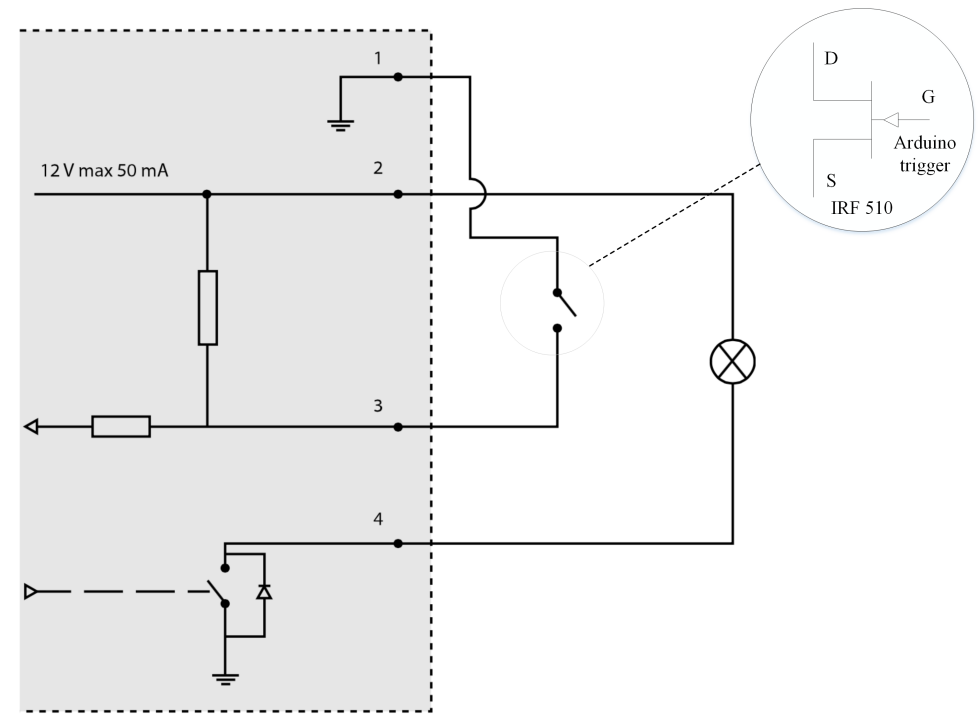

Figure 3.4: I/O pins of Axis Q1614 (Source: [1]) 
An nMOSFET transistor (IRF510) is used to implement the switch as shown in Figure 3.4. The trigger input from the processor is connected to the gate terminal. Drain and source terminals are connected to the I/O pins 3 and 1 of the camera respectively. The source terminal is grounded via pin 1. When trigger input is high, video or image is captured. Camera trigger system was used to test the system's efficiency which will be discussed in Chapter 4 .

\subsection{Research of Sensor Technologies}

The selection of a sensor for this kind of application is a challenging task. Sensor technology can be classified as visual and non-visual. Visual based sensors include still and video cameras, while non-visual based sensors includes infrared, ultrasonic, and microwave sensors.

\subsubsection{Visual Sensors}

Visual based detection of a vehicle uses video cameras. Video image cameras use image processing and license plate recognition techniques to detect vehicles [6]. Cameras installed at both the entrance and exit of the parking lot are used to maintain an overall vehicle count. Image processing techniques are used to detect a vehicle [9]. A vacant spot is detected by installing a camera for three spots. License plate recognition identifies the vehicle and its information [12]. Using this system on a large scale involves high installation costs.

Visual based detection methods have a drawback in accuracy as they are easily affected by environmental conditions. The primary problems are occlusion effects, shadow effects [9] and improper

lighting conditions. A fully occupied space can be counted vacant in high lighting conditions, and an empty space may be considered occupied in poor lighting conditions due to shadow effects [9]. Further research has been done in identifying a reliable sensor to detect a vehicle. 


\subsubsection{Non-Visual Sensors}

A detailed study of sensors that can be mounted on the roof of the parking garage are considered. Specific sensor technologies are active and passive infrared sensors, ultrasonic sensors, and microwave sensors. The characteristics of these sensors studied are supply voltage, current consumption, power consumption, output type, accuracy, cost, operating temperature, range, and sensing area of the sensor (Table 3.1).

After a thorough review of characteristics from Table 3.1, these sensors are compared in Table 3.2 that helps in the proper selection of the sensor. The system requirements are $5 \mathrm{~m}$ range, $4-5 \mathrm{~m}^{2}$ of sensitive area and few dollars cost. Active infrared, passive infrared (PIR) and microwave sensors are ruled out for our application for several reasons. Active infrared has a short range of detection of $1.5 \mathrm{~m}$. Standard PIR has a excessively wide sensing area of $41.92 \mathrm{~m}^{2}$. Slight PIR has poor range of detection of $2 \mathrm{~m}$. 10-meter detection PIR has large sensing area of $195.57 \mathrm{~m}^{2}$, which is too high for this application. Ideally we want the sensing area to be wide enough to accommodate a standard vehicle. Microwave sensor requires external installation of an antenna that requires its maintenance. Ultrasonic sensor stands out to be the most reliable, efficient, and economical sensor. It has an acceptable range of detection of $4.5 \mathrm{~m}$ and a safe operating range of temperature of $-10^{\circ} \mathrm{C}$ to $+50^{\circ} \mathrm{C}$. It is efficient because it has a fast response time of 25 milliseconds and sensing angle of $15^{\circ}$. It is economical because it is available for less than $\$ 2$ and easy to install in the field. 
Table 3.1: Characteristics of sensors

\begin{tabular}{|c|c|c|c|c|c|c|c|c|c|}
\hline Sensor & $\begin{array}{c}\text { DC } \\
\text { Supply } \\
\text { (Volts) }\end{array}$ & $\begin{array}{c}\text { Current } \\
\mathrm{mA}\end{array}$ & $\begin{array}{c}\text { Power } \\
\mathrm{mW}\end{array}$ & $\begin{array}{c}\text { Output } \\
\text { Type }\end{array}$ & Accuracy & $\begin{array}{c}\text { Cost } \\
(\$)\end{array}$ & $\begin{array}{c}\text { Operating } \\
\text { Temp } \\
\left({ }^{\circ} \mathrm{C}\right)\end{array}$ & $\begin{array}{l}\text { Range } \\
(\mathrm{m})\end{array}$ & $\begin{array}{c}\text { Area } \\
m^{2}\end{array}$ \\
\hline $\begin{array}{c}\text { Active } \\
\text { Infrared } \\
\text { Sensor }\end{array}$ & $\begin{array}{l}4.5 \\
\text { to } \\
5.5\end{array}$ & 33 & 165 & Analog & $\begin{array}{c}10 \mathrm{~cm} \\
\text { to } \\
30 \mathrm{~cm}\end{array}$ & $\$ 14$ & $\begin{array}{c}-10^{\circ} \\
\text { to } \\
+60^{\circ}\end{array}$ & $\begin{array}{c}0.2 \\
\text { to } \\
1.5\end{array}$ & - \\
\hline $\begin{array}{c}\text { Passive } \\
\text { Infrared } \\
\text { Sensor } \\
\text { (Standard } \\
\text { Detection } \\
\text { Type) }\end{array}$ & $\begin{array}{l}4.5 \\
\text { to } \\
5.5\end{array}$ & 0.1 & 2 & $\begin{array}{c}\text { Digital } \\
\text { and } \\
\text { Analog }\end{array}$ & $\begin{array}{c}\text { Accurate } \\
\text { within } \\
\text { range }\end{array}$ & $\$ 15$ & $\begin{array}{c}-20^{\circ} \\
\text { to } \\
+60^{\circ}\end{array}$ & $\begin{array}{c}0 \\
\text { to } \\
5\end{array}$ & $\begin{array}{c}41.9 \\
m^{2}\end{array}$ \\
\hline $\begin{array}{l}\text { Passive } \\
\text { Infrared } \\
\text { Sensor } \\
\text { (Spot } \\
\text { Detection } \\
\text { Type) }\end{array}$ & $\begin{array}{c}3 \\
\text { to } \\
6\end{array}$ & 0.17 & $\begin{array}{c}0.57 \\
\text { to } \\
0.85\end{array}$ & $\begin{array}{c}\text { Digital } \\
\text { and } \\
\text { Analog }\end{array}$ & $\begin{array}{c}\text { Accurate } \\
\text { within } \\
\text { range }\end{array}$ & $\$ 15$ & $\begin{array}{l}-20^{\circ} \\
\text { to } \\
+60^{\circ}\end{array}$ & $\begin{array}{c}0 \\
\text { to } \\
5\end{array}$ & $\begin{array}{l}2.8 \\
m^{2}\end{array}$ \\
\hline $\begin{array}{l}\text { Passive } \\
\text { Infrared } \\
\text { Sensor } \\
\text { (Slight } \\
\text { Detection } \\
\text { Type) }\end{array}$ & 5 & $\begin{array}{c}0.17 \\
\text { to } \\
0.3\end{array}$ & $\begin{array}{c}0.85 \\
\text { to } \\
1.5\end{array}$ & $\begin{array}{c}\text { Digital } \\
\text { and } \\
\text { Analog }\end{array}$ & $\begin{array}{c}\text { Accurate } \\
\text { within } \\
\text { range }\end{array}$ & $\$ 15$ & $\begin{array}{c}-20^{\circ} \\
\text { to } \\
+60^{\circ}\end{array}$ & $\begin{array}{c}0 \\
\text { to } \\
2\end{array}$ & $\begin{array}{c}19.6 \\
m^{2}\end{array}$ \\
\hline $\begin{array}{l}\text { Passive } \\
\text { Infrared } \\
\text { Sensor } \\
(10 \mathrm{~m} \\
\text { Detection } \\
\text { Type) }\end{array}$ & 5 & $\begin{array}{c}0.17 \\
\text { to } \\
0.3\end{array}$ & $\begin{array}{c}0.85 \\
\text { to } \\
1.5\end{array}$ & $\begin{array}{c}\text { Digital } \\
\text { and } \\
\text { Analog }\end{array}$ & $\begin{array}{c}\text { Accurate } \\
\text { within } \\
\text { range }\end{array}$ & $\$ 15$ & $\begin{array}{c}-20^{\circ} \\
\text { to } \\
+60^{\circ}\end{array}$ & $\begin{array}{c}0 \\
\text { to } \\
10\end{array}$ & $\begin{array}{l}196 \\
m^{2}\end{array}$ \\
\hline $\begin{array}{l}\text { Microwave } \\
\text { Sensor }\end{array}$ & $\begin{array}{l}4.75 \\
\text { to } \\
5.25\end{array}$ & $\begin{array}{l}30 \\
\text { to } \\
40\end{array}$ & $\begin{array}{c}15 \\
\text { to } \\
100\end{array}$ & $\begin{array}{c}\text { Digital } \\
\text { and } \\
\text { Analog }\end{array}$ & $\begin{array}{l}\text { Accurate } \\
\text { within } \\
\text { set } \\
\text { frequency }\end{array}$ & $\$ 10$ & $\begin{array}{c}-15^{\circ} \\
\text { to } \\
+55^{\circ}\end{array}$ & $\begin{array}{c}\text { Varies } \\
\text { on } \\
\text { set } \\
\text { freq. }\end{array}$ & - \\
\hline $\begin{array}{l}\text { Ultrasonic } \\
\text { Sensor }\end{array}$ & 5 & 20 & 100 & Digital & $\begin{array}{c}\text { High } \\
\text { accuracy } \\
\text { up to } \\
3 \mathrm{~mm}\end{array}$ & $\$ 2$ & $\begin{array}{c}-10^{\circ} \\
\text { to } \\
+50^{\circ}\end{array}$ & $\begin{array}{c}0.02 \\
\text { to } \\
4.5\end{array}$ & $\begin{array}{l}1.1 \\
m^{2}\end{array}$ \\
\hline
\end{tabular}

\subsection{Vehicle Detection by Ultrasonic Sensor}

Vehicle detection in this system is achieved with HC-SR04, an ultrasonic sensor. This sensor offers an excellent non-contact range detection with high accuracy. HC-SR04 consists of a transmitter 
Table 3.2: Comparison of sensors considered for vehicle detection

\begin{tabular}{|c|c|c|c|c|c|}
\hline Sensor & $\begin{array}{c}\text { Power } \\
\text { Consumption }\end{array}$ & $\begin{array}{l}\text { Analysis } \\
\text { of Range }\end{array}$ & $\begin{array}{c}\text { Analysis } \\
\text { of Cost }\end{array}$ & Installation & $\begin{array}{c}\text { Sensing } \\
\text { Area }\end{array}$ \\
\hline $\begin{array}{l}\text { Active Infrared } \\
\text { Sensor }\end{array}$ & High & Poor & Low & $\begin{array}{c}\text { Easy to } \\
\text { install }\end{array}$ & - \\
\hline $\begin{array}{c}\text { Passive Infrared } \\
\text { Sensor } \\
\text { (Std. Detection } \\
\text { Type) }\end{array}$ & Low & Good & High & $\begin{array}{c}\text { Easy to } \\
\text { install }\end{array}$ & Medium \\
\hline $\begin{array}{c}\text { Passive Infrared } \\
\text { Sensor } \\
\text { (Spot Detection } \\
\text { Type) }\end{array}$ & Low & Good & High & $\begin{array}{c}\text { Easy to } \\
\text { install }\end{array}$ & Smaller \\
\hline $\begin{array}{c}\text { Passive Infrared } \\
\text { Sensor } \\
\text { (Slight Detection } \\
\text { Type) }\end{array}$ & Low & Poor & High & $\begin{array}{c}\text { Easy to } \\
\text { install }\end{array}$ & Smaller \\
\hline $\begin{array}{l}\text { Passive Infrared } \\
\text { Sensor } \\
\text { (10m Detection } \\
\text { Type) }\end{array}$ & Low & Good & High & $\begin{array}{c}\text { Easy to } \\
\text { install }\end{array}$ & Larger \\
\hline $\begin{array}{l}\text { Microwave } \\
\text { Sensor }\end{array}$ & $\begin{array}{l}\text { Low/ } \\
\text { Medium }\end{array}$ & Good & Medium & $\begin{array}{l}\text { Requires } \\
\text { antenna } \\
\text { to be } \\
\text { installed }\end{array}$ & - \\
\hline $\begin{array}{l}\text { Ultrasonic } \\
\text { Sensor }\end{array}$ & $\begin{array}{l}\text { Medium/ } \\
\text { High }\end{array}$ & Good & Low & $\begin{array}{c}\text { Easy to } \\
\text { install }\end{array}$ & Smaller \\
\hline
\end{tabular}

head that converts electric pulse to sound pulse, and a receiver head that converts sound pulse back to an electric pulse. The transmitter head sends a sound pulse and the receiver head receives it back if any obstacle is present within its range of detection. 


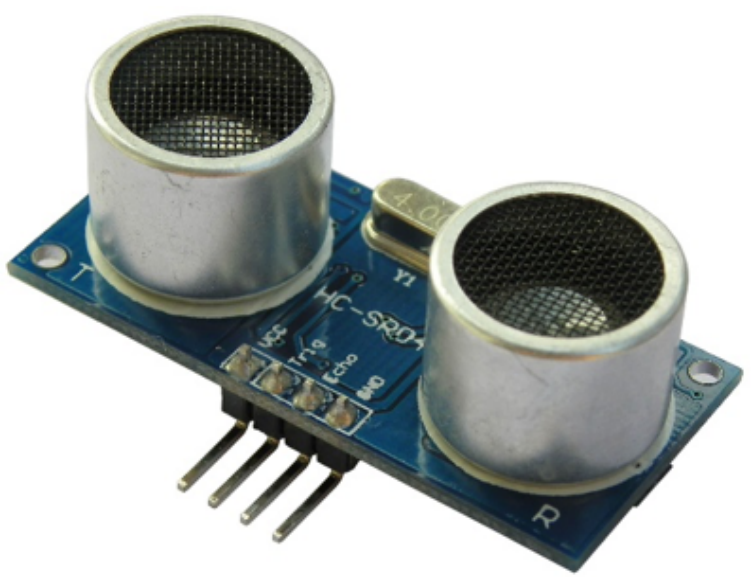

Figure 3.5: HC-SR04 ultrasonic sensor (Source: [2])

\subsection{Arduino Microcontroller Board}

Arduino UNO is the microcontroller board used in this application. It has easy to use hardware for prototyping, low cost and has simple software development interface. It contains ATmega328 microcontroller chip with a clock speed of $16 \mathrm{MHz}$, which accelerates the system response time. ATmega328 is a low power AVR 8-bit microcontroller with 2 KB SRAM. It has 23 programmable I/O lines of which Arduino UNO provides 12 digital I/O pins (2 - 13) and 6 analog I/O pins (A0 A5) as shown in Figure 3.6.

The trigger and echo pins of the ultrasonic sensor are connected to the digital pins 2 and 3 of the board respectively. After the system is powered on, the processor sends a pulse, starts an internal timer, and waits for a given timeout. If an obstacle is detected within the timeout, the processor receives the pulse through the echo pin and stops the timer. The processor returns the time taken by pulse to travel in microseconds. This time is used to calculate the distance of the obstacle, as explained in Section 3.5 later. If no obstacle is detected, the timer stops after the timeout and sends a pulse again. 


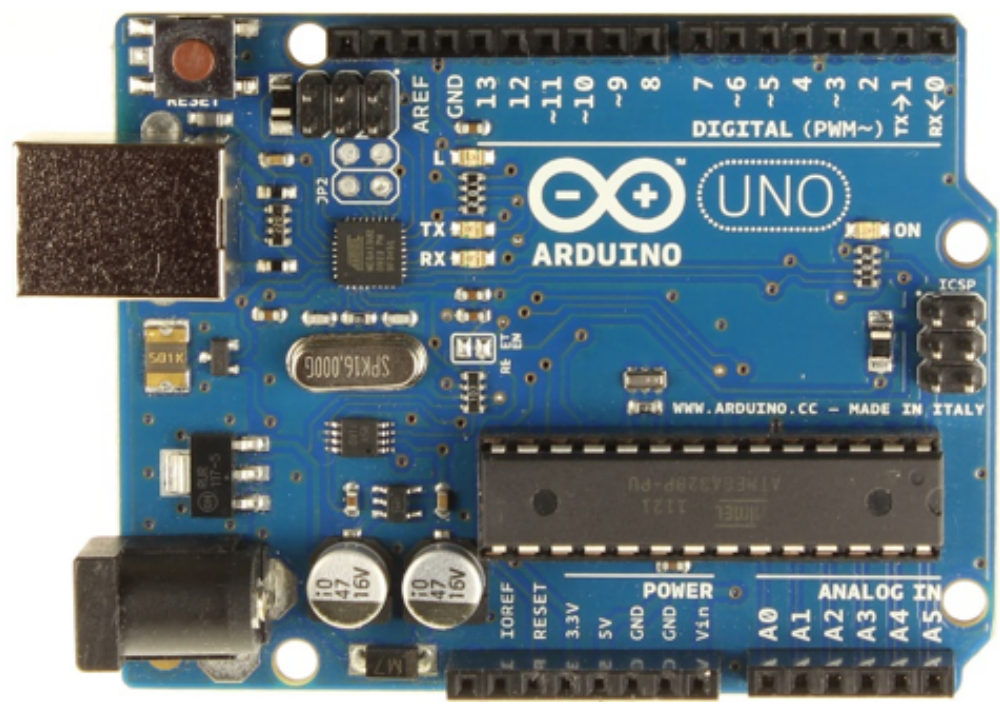

Figure 3.6: Arduino UNO

\subsection{Vehicle Detection Logic}

As discussed the controller pulses the ultrasonic sensor and calculates the time taken by the pulse to return. The distance of the obstacle is calculated using the speed of sound in air as the ultrasonic sensor works on the principle of sound waves. The speed of sound $(\mathrm{m} / \mathrm{s})$ in dry air at a given temperature (in Celsius) is given by Equation 3.1.

$$
\text { Estimated_Speed_of_Sound }=331.5+(0.6 * \text { Temperature })
$$

As the speed of sound varies with the air temperature, a temperature sensor is used to correct the errors due to changing weather conditions. The distance calculated is twice the actual distance as the pulse travels from the transmitter to an obstacle, bounces back from the obstacle, and finally reaches the receiver. The distance of obstacle is given by Equation 3.2.

$$
2 * \text { Distance_of_Obstacle }=\text { Speed_of_Sound } * \text { Time_Elapsed }
$$


The ultrasonic sensor is installed to the ceiling at entrance/exit in a parking garage so that it detects the ground as an obstacle. The distance between the sensor and ground is considered as Maximum Range. When the system is powered on, the processor pulses the sensor and calculates the maximum range. After calculating the maximum range, the processor pulses the sensor continuously and checks for a change in the range. When an obstacle enters/exits the garage, the obstacle height is calculated by comparing obstacle distance with maximum range. The obstacle height calculated is used for vehicle detection and is explained further in Section 3.5.1.

\subsubsection{Vehicle Detection and Count}

The flow chart of logic to detect and count vehicles using an ultrasonic sensor is shown in Figure 3.7. After initial field tests the minimum vehicle height is $50 \mathrm{~cm}$, and considered to be the minimum

threshold height. The controller calculates the temperature of the air and calculates the speed of sound from it. Then it generates a pulse and calculates the maximum range as discussed in above section. Next, the controller calculates the obstacle height by subtracting new obstacle distance from the maximum range. The minimum height of the vehicle is set as minimum threshold height, and the obstacle height is compared with it. If the obstacle height is greater than threshold height, then it is considered to be an obstacle that can be a vehicle. This loop repeats for every five milliseconds and checks for the presence of an obstacle (vehicle).

After detecting an obstacle, the count logic checks whether it is a vehicle or not. A vehicle is a lengthier object, so time taken by it to cross the sensor will be more than time taken by the processor to complete one loop. The processor is so fast that it can complete a loop within 5 milliseconds, as discussed above for obstacle detection. For this reason, experiments are conducted to determine a minimum number of pulses a vehicle can take to cross the sensor, and minimum pulse width threshold 


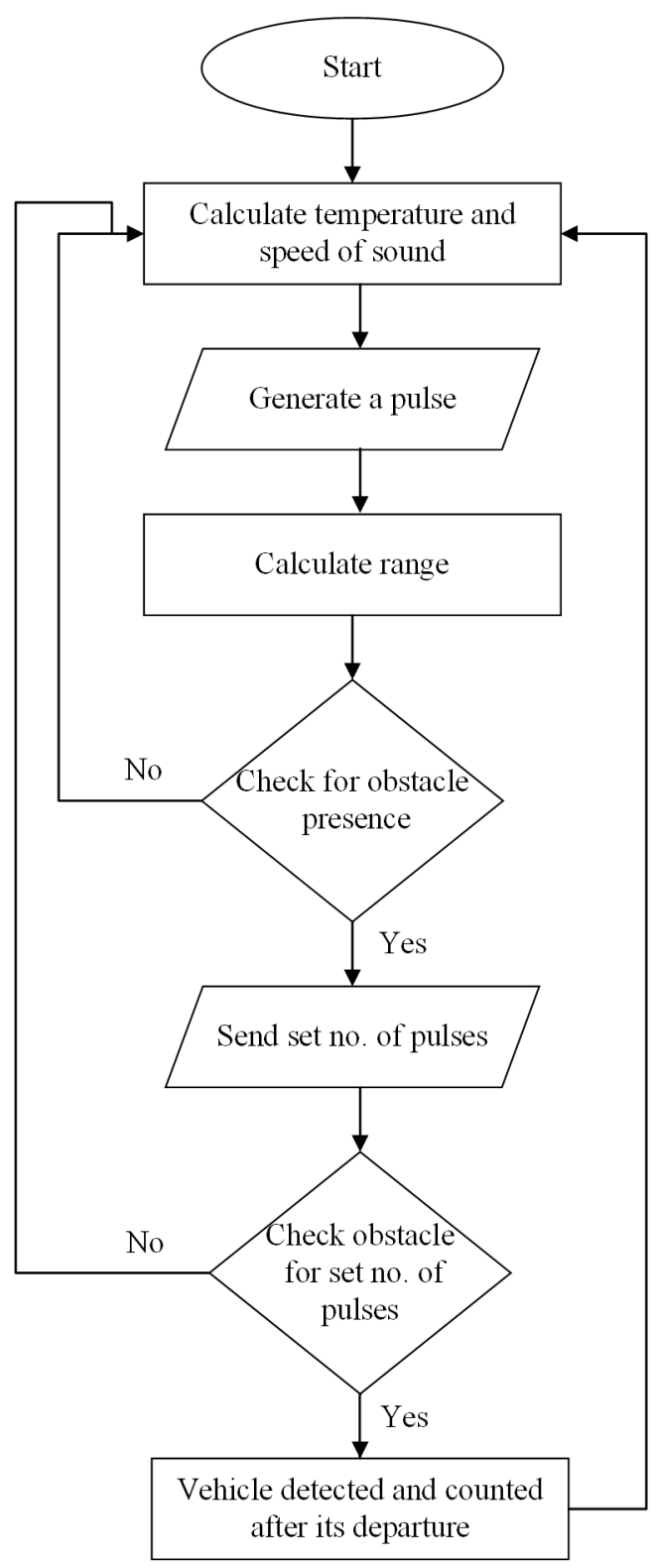

Figure 3.7: Flow chart of the logic to count the number of vehicles

is calculated. These calibration experiments are discussed in Chapter 4. Figure 3.7 shows the logic employed for vehicle count. First, an obstacle is detected using the detection logic. If no obstacle is detected, the processor stays in the inner loop to detect the obstacle. If any obstacle is detected, then the processor enters the outer loop and checks the obstacle for minimum pulse width threshold by 
sending a set number of pulses. The processor exits out of this loop, if obstacle does not satisfy the condition specified. If the obstacle satisfies the required condition, i.e., it is present for minimum pulse width threshold, then processor determines that it is a vehicle and increments/decrements vehicle count. If vehicle stays under the sensor for a longer time, the processor enters the outer loop, waits until the vehicle leaves the sensor arena. This logic is accurate which can record overall count of the parking garage.

\subsubsection{Camera Trigger}

The parking guidance system is used to trigger a camera as discussed above in Section 3.1.3. This section explains the logic involved in triggering the camera. The same logic used for vehicle detection and count is used to trigger the camera.

The logic is same except that when a vehicle is detected, a digital pin on Arduino is set high which is connected to the I/O pin of the Axis Q1614 camera. Upon receiving the pulse, the camera can be configured to send a video/image to the web server. These images are used to validate the system as discussed in Chapter 4.

\subsection{Power Consumption}

The current consumption of the devices used by the system components are given in Table 3.3. The supply voltage is $5 \mathrm{~V}$. Arduino consumes $232.5 \mathrm{~mW}$, ultrasonic sensor consumes $100 \mathrm{~mW}$, and temperature sensor consumes $0.25 \mathrm{~mW}$. The overall power consumption of the vehicle detection and count system is $332.75 \mathrm{~mW}$. 
Table 3.3: Current consumption of the components used in the system

\begin{tabular}{|c|c|c|c|}
\hline Name of the component & Low power mode & Working current & Idle mode \\
\hline Arduino UNO & $34.4 \mathrm{~mA}$ & $46.5 \mathrm{~mA}$ & - \\
\hline Ultrasonic Sensor & $10.0 \mathrm{~mA}$ & $20 \mathrm{~mA}$ & $15 \mathrm{~mA}$ \\
\hline Temperature Sensor & $0.5 \mu \mathrm{A}$ & $50.0 \mu \mathrm{A}$ & - \\
\hline
\end{tabular}

\subsection{System Cost}

The proposed parking guidance is cost-efficient. TMP-36 is the temperature sensor used, and IRF510 is the nMOSFET used. The cost of each component is given in Table 3.4.

Table 3.4: Cost of the components used in the system

\begin{tabular}{|c|c|}
\hline Name of the component & Cost of the component \\
\hline Arduino UNO & $\$ 25$ \\
\hline HC-SR04 & $\$ 1$ \\
\hline TMP-36 & $\$ 1.50$ \\
\hline IRF510 & $\$ 1$ \\
\hline
\end{tabular}

The cost of different features of the system are given in Table 3.5. The overall cost of the system to detect and count the number of vehicles entering the parking lot is less than $\$ 30$ per each entrance/exit. Triggering a camera uses the same system used for vehicle detection and count. The cost of the system for this is less than $\$ 30$ per each entrance/exit. All these costs can be still reduced by designing custom PCB with ATmega328 microcontroller for their application.

Table 3.5: Cost of different features of the system

\begin{tabular}{|c|c|c|}
\hline & Simple count system & Decal detection type based system \\
\hline Arduino UNO & 1 per entrance/exit & 1 per entrance/exit \\
\hline HC-SR04 & 1 per entrance/exit & 1 per entrance/exit \\
\hline TMP-36 & 1 per entrance/exit & 1 per entrance/exit \\
\hline IRF510 & Not Required & 1 per entrance/exit \\
\hline System Cost & $\$ 28$ & $\$ 30$ \\
\hline
\end{tabular}




\subsection{Chapter Summary}

We presented in detail the designed parking guidance system. The different features of the system are shown in system block diagram and the logic involved for each of them is discussed. Also, research on sensor technologies was done to select a reliable sensor for this application. The hardware used

for the system is also discussed. The power consumption of the system is calculated. The overall cost of the system is estimated. 


\section{CHAPTER 4 : EXPERIMENTAL RESULTS}

After a thorough study of the ultrasonic sensor, experiments were conducted to test the sensor. Experimental setup required was designed to test the sensor in the field. The sensor was calibrated and initial feasibility tests were performed at Richard Beard Garage at the University of South Florida during weekends. Initial test data collected was by driving cars at various speeds. These results were analyzed and logic was developed for vehicle detection and count. Later, this system along with Axis Q1614 camera was deployed on the west entrance of Richard Beard Garage to run several trials to validate system.

\subsection{Experimental Setup}

A simple detection box is enough for data collection of vehicle detection as shown in Figure 4.1. The detector includes an ultrasonic sensor, temperature sensor, connecting wires, and an Arduino microcontroller board. The sensor was connected to an Arduino microcontroller board using connecting cables. An external battery was used to power the system during the initial feasibility tests. A computer compiled code to the microcontroller board. This detector is mounted temporarily at a height of 2.4 meters. Vehicles driven exactly under the detector yielded good results. The system was powered by pulling power lines from the camera. 


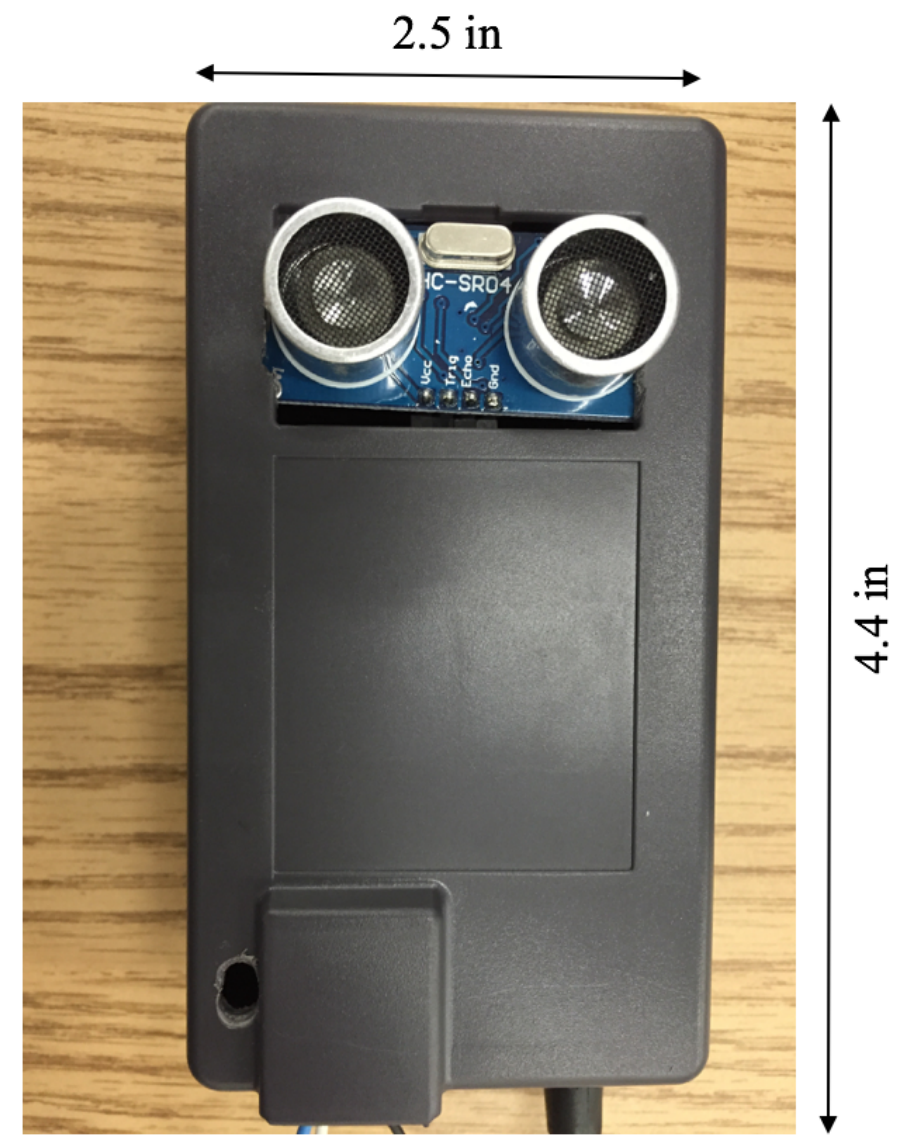

Figure 4.1: Parking system experimental setup

\subsection{Calibrating the Sensor}

The ultrasonic sensor works on the principle of acoustics. The speed of sound varies with the temperature of the air. A temperature sensor (TMP-36) is used to estimate the speed of sound. Also, when the system is powered on, the sensor should detect the ground surface first to calculate the maximum range. There should be no obstacle underneath the sensor during the system startup. 


\subsection{Results from Initial Feasibility Tests}

After installation of the sensor for vehicle detection, cars at various speeds drove underneath the sensor, the distances detected were analyzed, and variation of obstacle distances were calculated by the controller. ATmega328 triggers the pulse and calculates the echo time. The distance of the obstacle is calculated every $5 \mathrm{~ms}$. When a vehicle approaches the sensor, the distance of the obstacle changes and if we plot those distances on a graph we can expect an inverted shape of the car. The test results are shown in Figure 4.2 and Figure 4.3. The results attained from the first set of experiments to detect a vehicle using ultrasonic sensor were as expected. Three cars drove underneath the sensor and distances detected were plotted with distance in meters as $\mathrm{Y}$ axis and time in milliseconds as $\mathrm{X}$ axis. Figure 4.2 is the plot for the first trial and Figure 4.3 is the plot for the second trial. The curved portions of both plots indicate the presence of a car and flat region shows the absence of a car.

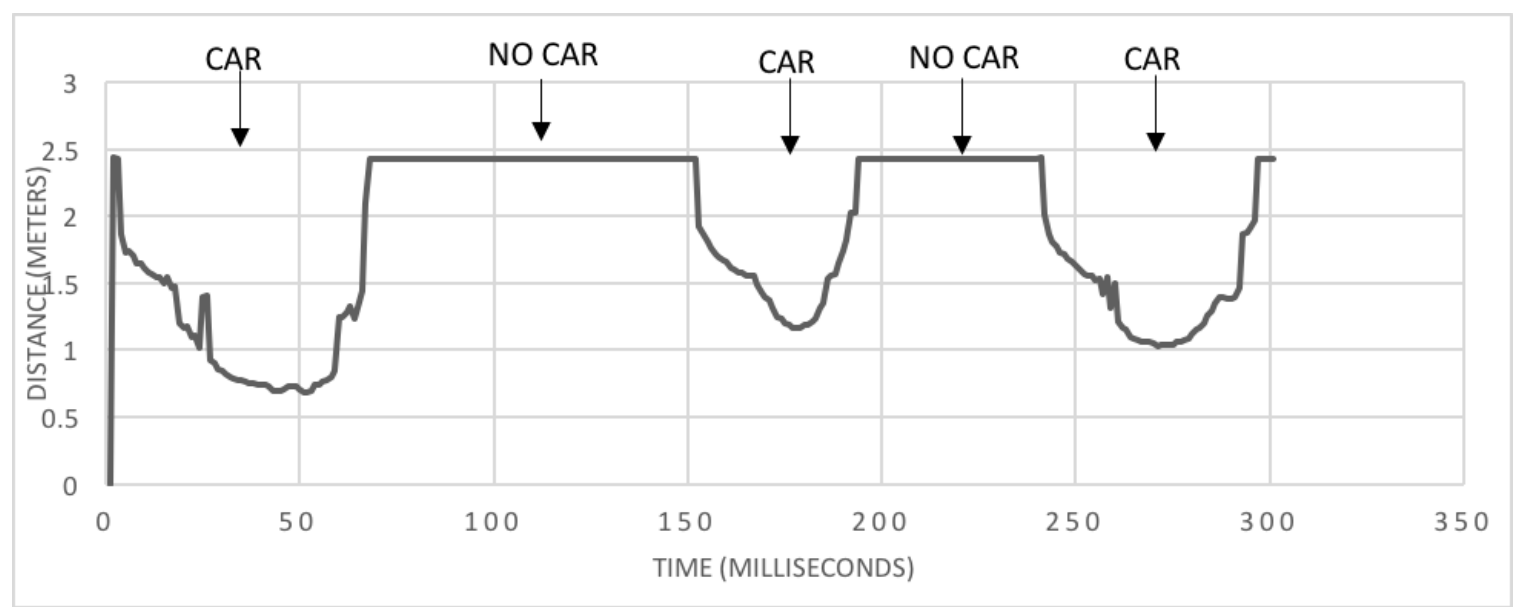

Figure 4.2: Plot of distances of slow moving vehicles (5 mph) 


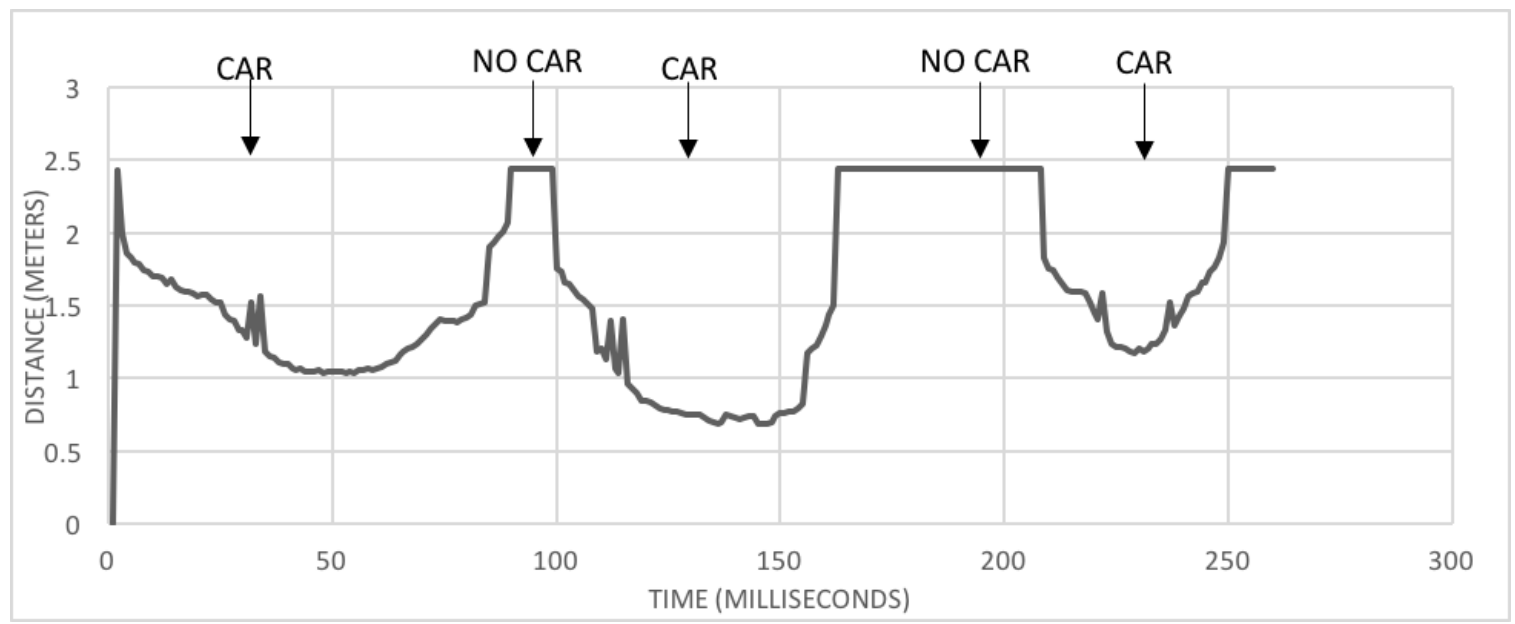

Figure 4.3: Plot of distances of fast moving vehicles $(20 \mathrm{mph})$

After analyzing the results acquired from preliminary tests, the minimum time taken by a fast moving vehicle to cross the sensor was less than 100 milliseconds (Figure 4.3). These preliminary tests gave a minimum number of pulses a vehicle can encounter. This data was used to set a minimum number of pulses, i.e., threshold pulse width, for vehicle count. This can eliminate the error of counting a person as a vehicle, because the pulse width of a vehicle is greater compared to a person.

\subsection{Field Trials}

The detector along with Axis Q1614 camera was deployed at the West entrance of Richard Beard Garage as shown in Figure 4.4 to test the working of the system. The power to the detector box was pulled from the camera. As discussed, Axis Q1614 is a network camera that can send images from the camera to the database when it is triggered. When a vehicle enters the garage, the sensor system triggers the camera, and the camera would send the images to the local database set up at Center for Urban Transportation and Research (CUTR). 

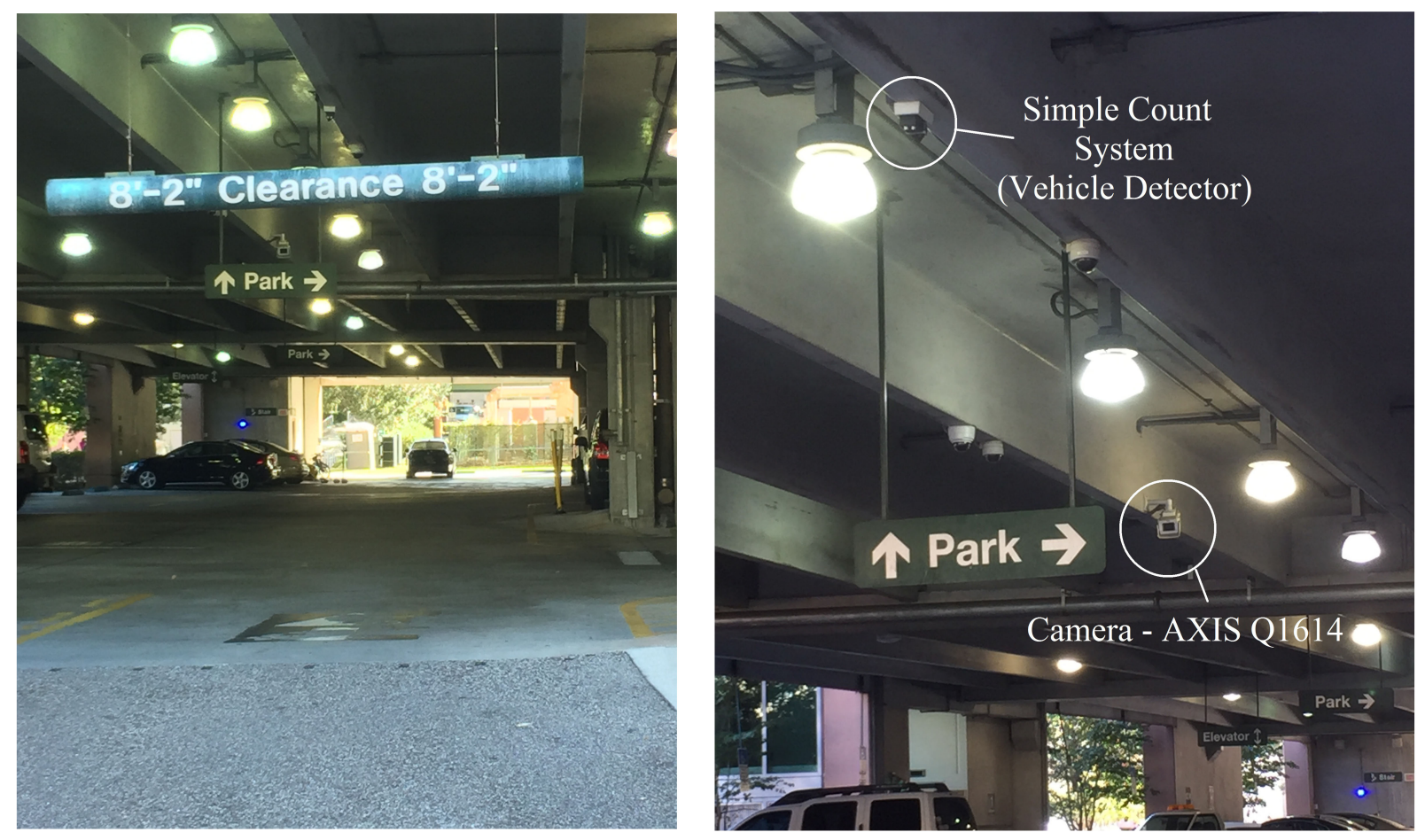

Figure 4.4: System installation at West entrance of Richard Beard Garage
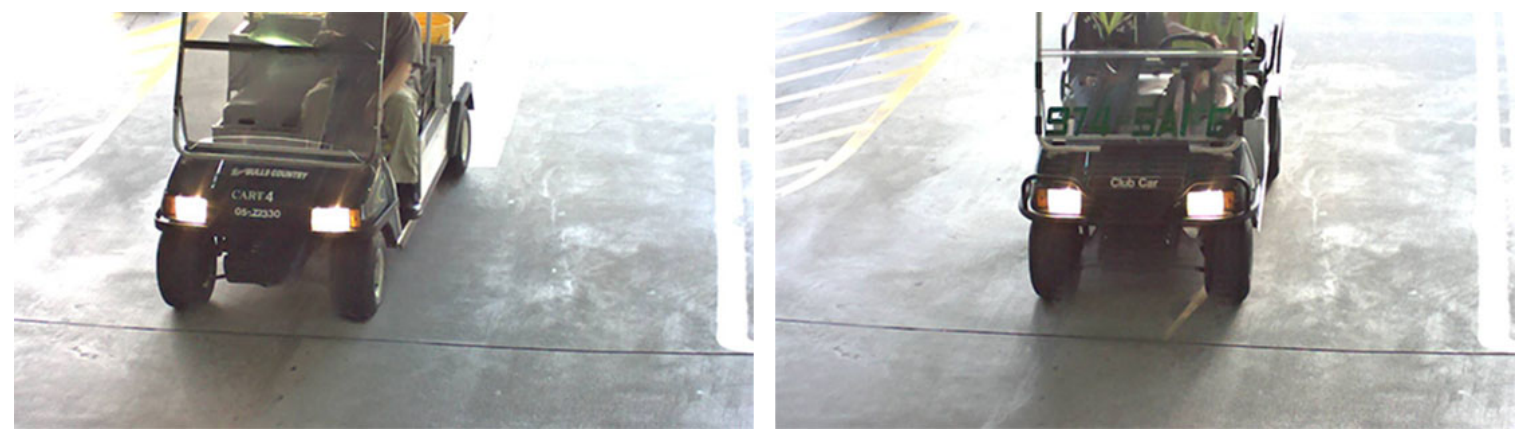

Figure 4.5: Example of a golf cart entering the garage

Tables 4.1 - 4.5 show the number of cars detected by the system for five days during trials. In the tables, "Golf Carts" are small vehicles as shown in Figure 4.5. "Exiting Cars" are cars exiting from the garage and detected as cars entering the garage as shown in Figure 4.6. "People" are persons entering the garage and detected as cars as shown in Figure 4.7. "Cars Detected" are the total number of vehicles identified as cars by the system and "Actual Cars" are the cars that actually 

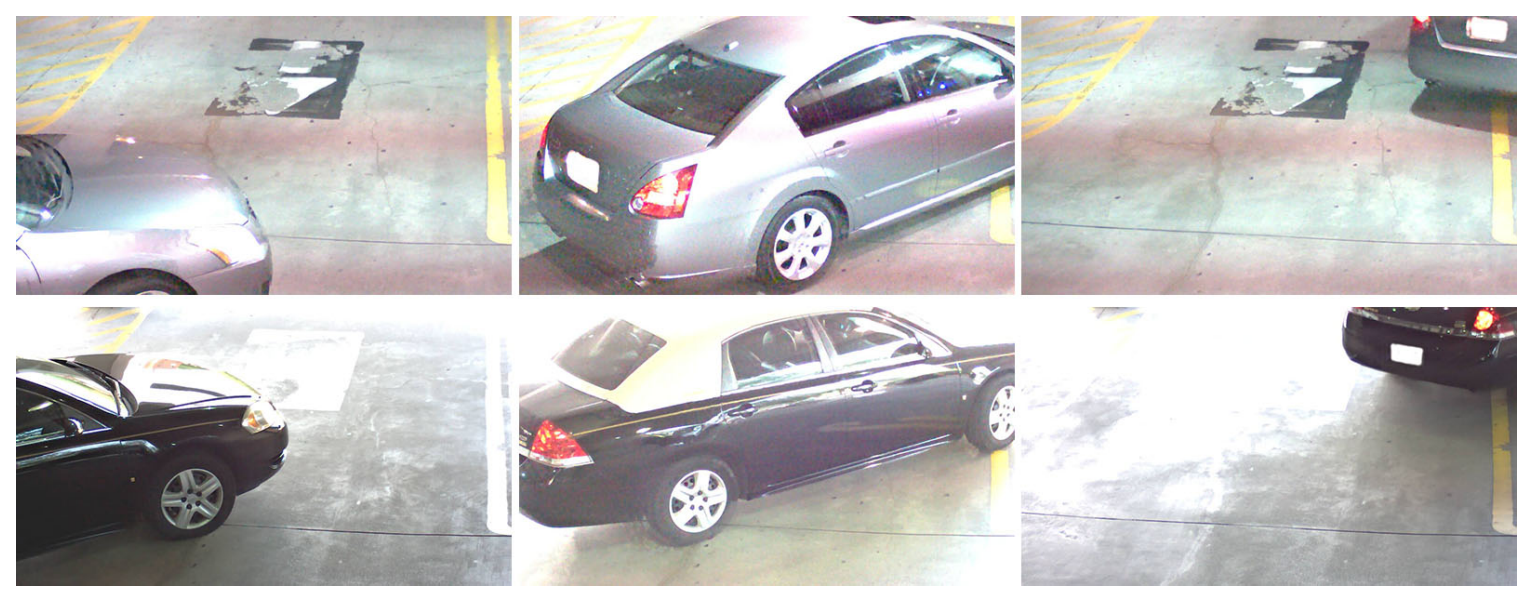

Figure 4.6: Example of cars exiting from the garage

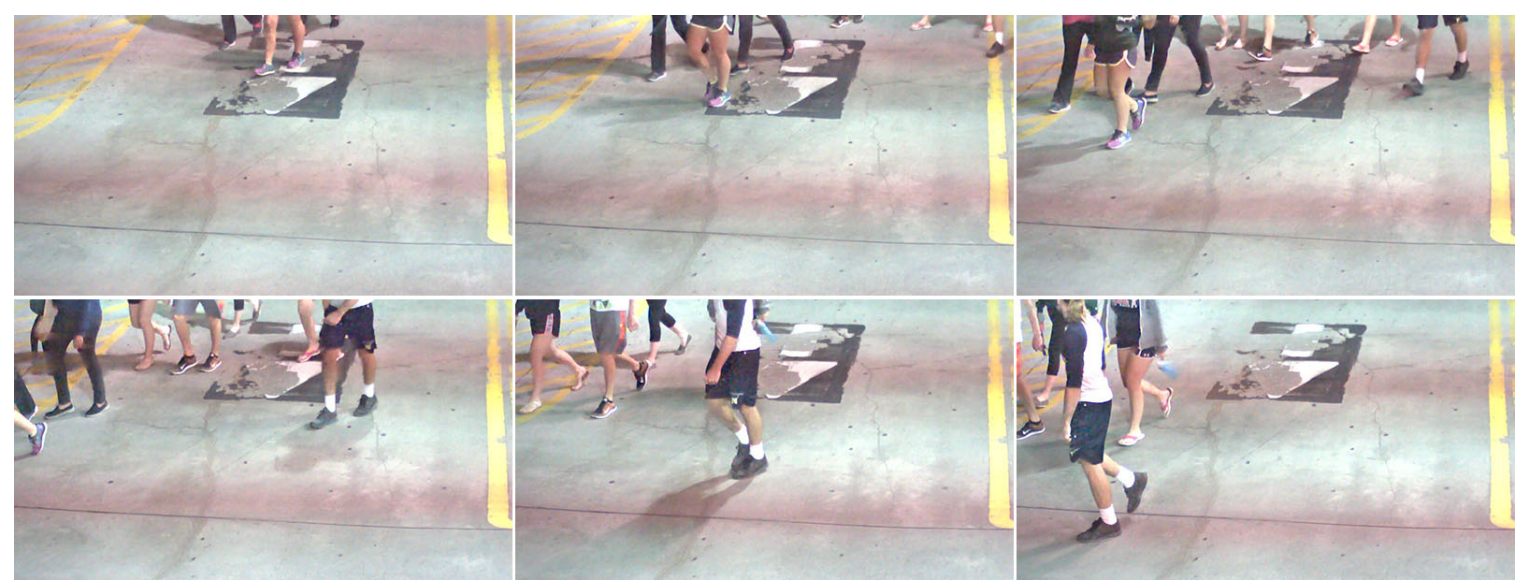

Figure 4.7: Example of people walking under the sensor

entered the garage excluding the golf carts, exiting cars, and people. Error percentage is calculated for each day and shown in each table. The Richard Beard Garage has a total of 3000 spots. It was determined that $5 \%$ to be an acceptable margin of error with system reset every month.

Table 4.1 shows the data collected for April 15 to April 16, 2015. By end of 24 hours, there was an error of $4.56 \%$. $21 \%$ of error was due to Golf carts, $66 \%$ of the error was due to exiting cars and $13 \%$ error was due to people entering the garage. The "Cars Detected" and "Actual Cars" detected of Table 4.1 are compared and plotted against the "Hour" and shown in Figure 4.8. 
Table 4.1: Day 1 - April 15 to April 16, 2015

\begin{tabular}{|l|c|c|c|c|c|c|c|}
\hline Hour & $\begin{array}{c}\text { Cars } \\
\text { detected }\end{array}$ & $\begin{array}{c}\text { Actual } \\
\text { cars }\end{array}$ & $\begin{array}{c}\text { Golf } \\
\text { Carts }\end{array}$ & $\begin{array}{c}\text { Exiting } \\
\text { Cars }\end{array}$ & People & Error & $\begin{array}{c}\text { Percent } \\
\text { Error }\end{array}$ \\
\hline $6.40-7.40 \mathrm{pm}$ & 19 & 17 & 2 & 0 & 0 & 2 & 11.76 \\
\hline $7.40-8.40 \mathrm{pm}$ & 19 & 16 & 1 & 2 & 0 & 3 & 18.75 \\
\hline $8.40-9.40 \mathrm{pm}$ & 20 & 17 & 0 & 3 & 0 & 3 & 17.64 \\
\hline $9.40-10.40 \mathrm{pm}$ & 34 & 28 & 1 & 3 & 2 & 6 & 21.42 \\
\hline $10.40-11.40 \mathrm{pm}$ & 26 & 23 & 1 & 2 & 0 & 3 & 13.04 \\
\hline $11.40-12.40 \mathrm{am}$ & 19 & 18 & 0 & 1 & 0 & 1 & 5.55 \\
\hline $12.40-1.40 \mathrm{am}$ & 16 & 13 & 0 & 3 & 0 & 3 & 23.07 \\
\hline $1.40-2.40 \mathrm{am}$ & 8 & 8 & 0 & 0 & 0 & 0 & 0 \\
\hline $2.40-3.40 \mathrm{am}$ & 8 & 8 & 0 & 0 & 0 & 0 & 0 \\
\hline $3.40-4.40 \mathrm{am}$ & 1 & 1 & 0 & 0 & 0 & 0 & 0 \\
\hline $4.40-5.40 \mathrm{am}$ & 1 & 1 & 0 & 0 & 0 & 0 & 0 \\
\hline $5.40-6.40 \mathrm{am}$ & 7 & 5 & 1 & 1 & 0 & 2 & 40 \\
\hline $6.40-7.40 \mathrm{am}$ & 31 & 31 & 0 & 0 & 0 & 0 & 0 \\
\hline $7.40-8.40 \mathrm{am}$ & 82 & 81 & 0 & 0 & 1 & 1 & 1.23 \\
\hline $8.40-9.40 \mathrm{am}$ & 167 & 166 & 0 & 0 & 1 & 1 & 0.60 \\
\hline $9.40-10.40 \mathrm{am}$ & 125 & 124 & 0 & 1 & 0 & 1 & 0.80 \\
\hline $10.40-11.40 \mathrm{am}$ & 150 & 148 & 0 & 2 & 0 & 2 & 1.35 \\
\hline $11.40-12.40 \mathrm{pm}$ & 160 & 157 & 1 & 2 & 0 & 3 & 1.91 \\
\hline $12.40-1.40 \mathrm{pm}$ & 101 & 98 & 1 & 2 & 0 & 3 & 3.06 \\
\hline $1.40-2.40 \mathrm{pm}$ & 90 & 85 & 3 & 2 & 0 & 5 & 5.88 \\
\hline $2.40-3.40 \mathrm{pm}$ & 65 & 62 & 1 & 2 & 0 & 3 & 4.83 \\
\hline $3.40-4.40 \mathrm{pm}$ & 54 & 46 & 0 & 5 & 3 & 8 & 17.39 \\
\hline $4.40-5.40 \mathrm{pm}$ & 69 & 63 & 0 & 6 & 0 & 6 & 9.52 \\
\hline $5.40-6.40 \mathrm{pm}$ & 33 & 32 & 0 & 1 & 0 & 1 & 3.12 \\
\hline $24 \mathrm{hours}$ & 1305 & 1248 & 12 & 38 & 7 & 57 & 4.56 \\
\hline
\end{tabular}

Table 4.2 shows the data collected from April 21 to April 22, 2015. By the end of 24 hours, there was an error of $4.75 \%$. $13 \%$ of error was due to Golf carts, $84 \%$ of the error was due to exiting cars and 3\% error was due to people entering the garage. The "Cars Detected" and "Actual Cars" detected of Table 4.2 are compared and plotted against the "Hour" and shown in Figure 4.9. 


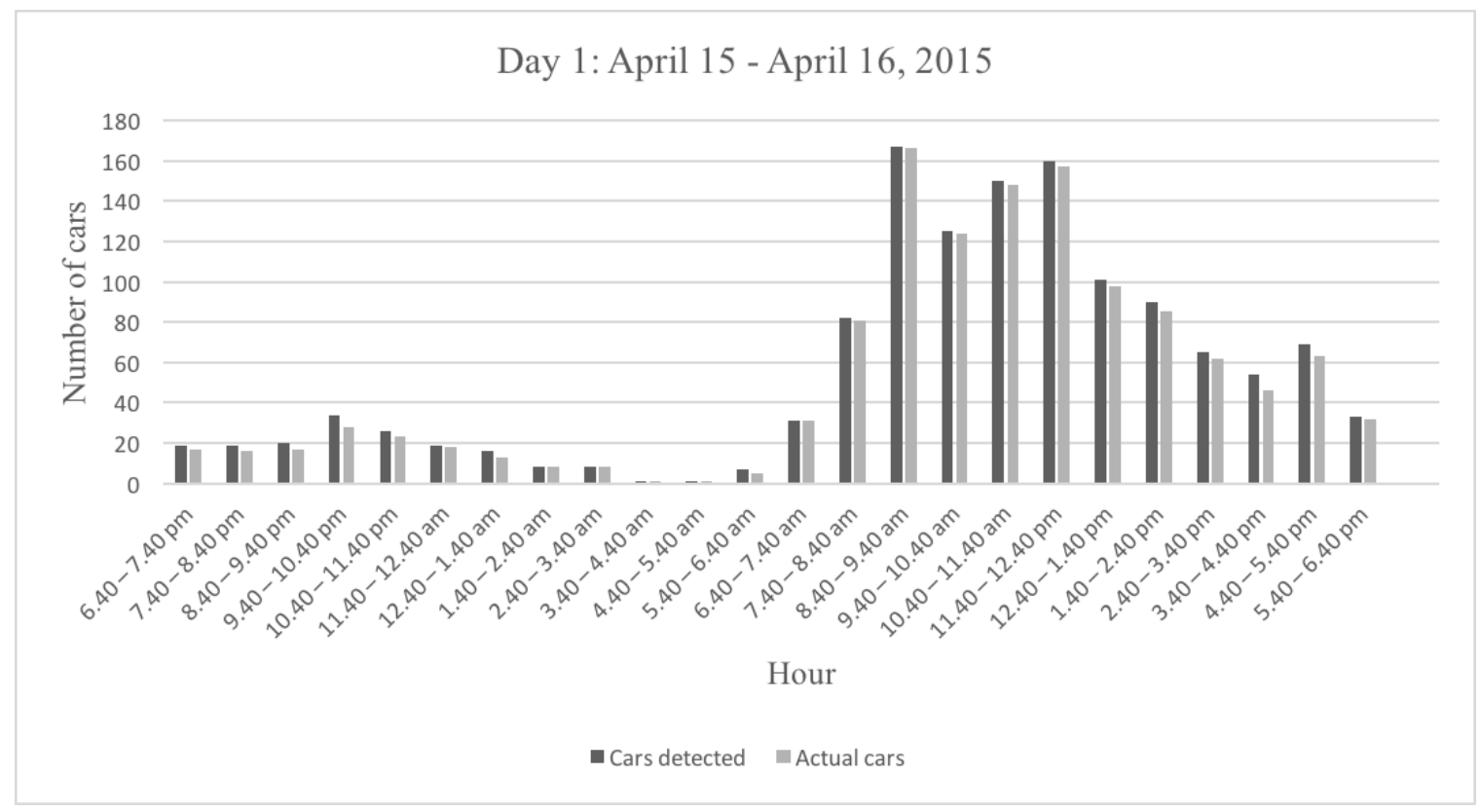

Figure 4.8: Day 1 plot

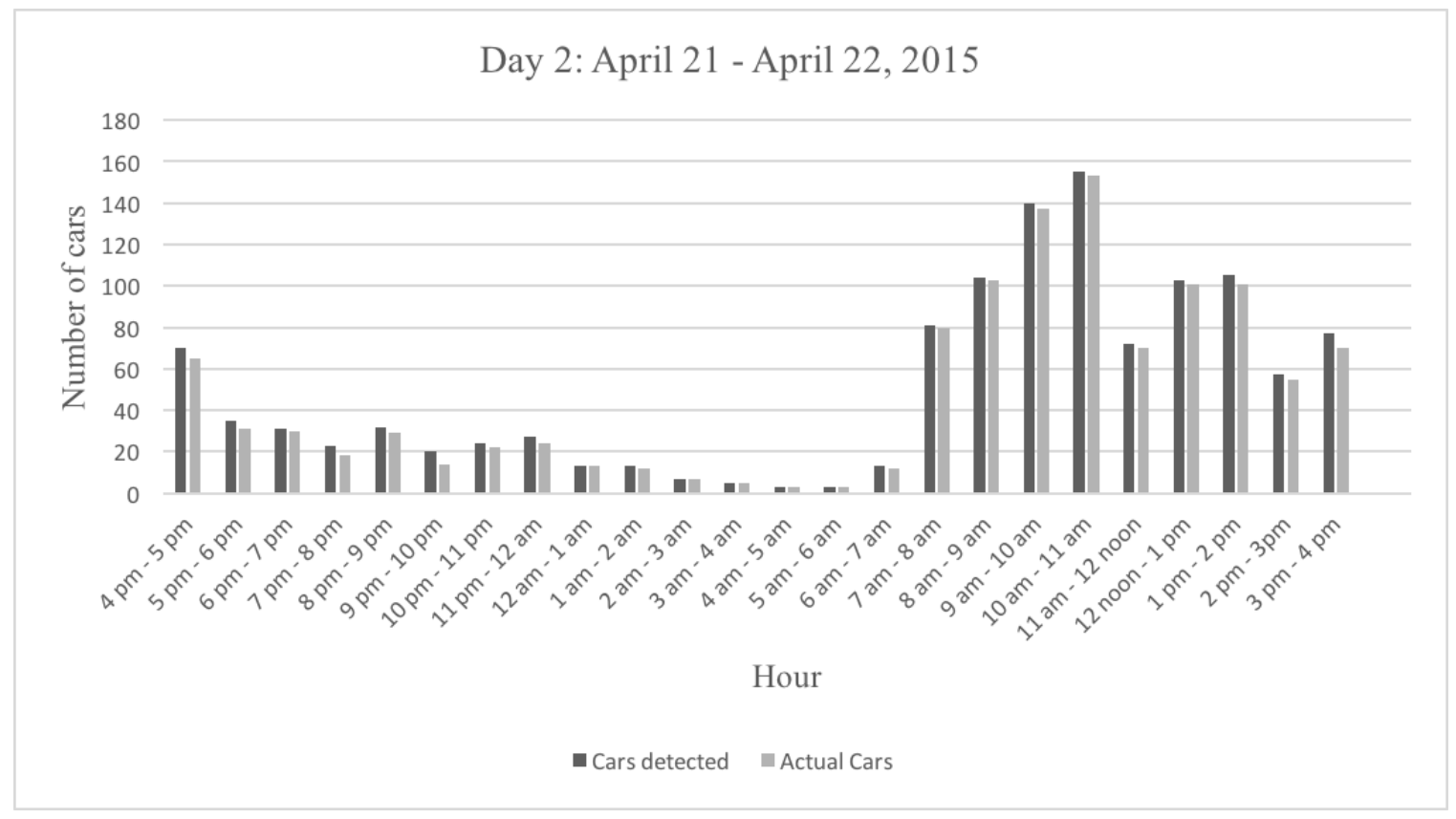

Figure 4.9: Day 2 plot

Table 4.3 shows the data collected from April 22 to April 23, 2015. By the end of 24 hours, there was an error of $4.64 \%$. $20 \%$ of error was due to Golf carts, $62 \%$ of the error was due to exiting 
Table 4.2: Day 2 - April 21 to April 22, 2015

\begin{tabular}{|l|c|c|c|c|c|c|c|}
\hline Hour & $\begin{array}{c}\text { Cars } \\
\text { detected }\end{array}$ & $\begin{array}{c}\text { Actual } \\
\text { cars }\end{array}$ & $\begin{array}{c}\text { Golf } \\
\text { Carts }\end{array}$ & $\begin{array}{c}\text { Exiting } \\
\text { Cars }\end{array}$ & People & Error & $\begin{array}{c}\text { Percent } \\
\text { Error }\end{array}$ \\
\hline $4-5 \mathrm{pm}$ & 70 & 65 & 0 & 5 & 0 & 5 & 7.70 \\
\hline $5-6 \mathrm{pm}$ & 35 & 31 & 0 & 4 & 0 & 4 & 12.90 \\
\hline $6-7 \mathrm{pm}$ & 31 & 30 & 0 & 1 & 0 & 1 & 3.33 \\
\hline $7-8 \mathrm{pm}$ & 23 & 18 & 1 & 4 & 0 & 5 & 27.80 \\
\hline $8-9 \mathrm{pm}$ & 32 & 29 & 0 & 3 & 0 & 3 & 10.34 \\
\hline $9-10 \mathrm{pm}$ & 20 & 14 & 0 & 6 & 0 & 6 & 42.85 \\
\hline $10-11 \mathrm{pm}$ & 24 & 22 & 0 & 1 & 1 & 2 & 9.10 \\
\hline $11-12 \mathrm{am}$ & 27 & 24 & 0 & 3 & 0 & 3 & 12.50 \\
\hline $12-1 \mathrm{am}$ & 13 & 13 & 0 & 0 & 0 & 0 & 0 \\
\hline $1-2 \mathrm{am}$ & 13 & 12 & 0 & 1 & 0 & 1 & 8.33 \\
\hline $2-3 \mathrm{am}$ & 7 & 7 & 0 & 0 & 0 & 0 & 0 \\
\hline $3-4 \mathrm{am}$ & 5 & 5 & 0 & 0 & 0 & 0 & 0 \\
\hline $4-5 \mathrm{am}$ & 3 & 3 & 0 & 0 & 0 & 0 & 0 \\
\hline $5-6 \mathrm{am}$ & 3 & 3 & 0 & 0 & 0 & 0 & 0 \\
\hline $6-7 \mathrm{am}$ & 13 & 12 & 0 & 1 & 0 & 1 & 8.33 \\
\hline $7-8 \mathrm{am}$ & 81 & 80 & 0 & 1 & 0 & 1 & 1.25 \\
\hline $8-9 \mathrm{am}$ & 104 & 103 & 1 & 0 & 0 & 1 & 0.98 \\
\hline $9-10 \mathrm{am}$ & 140 & 137 & 1 & 2 & 0 & 3 & 2.19 \\
\hline $10-11 \mathrm{am}$ & 155 & 153 & 1 & 1 & 0 & 2 & 1.31 \\
\hline $11-12 \mathrm{pm}$ & 72 & 70 & 0 & 2 & 0 & 2 & 2.86 \\
\hline $12-1 \mathrm{pm}$ & 103 & 101 & 0 & 1 & 1 & 2 & 1.98 \\
\hline $1-2 \mathrm{pm}$ & 105 & 101 & 1 & 3 & 0 & 4 & 3.96 \\
\hline $2-3 \mathrm{pm}$ & 57 & 55 & 1 & 1 & 0 & 2 & 3.64 \\
\hline $3-4 \mathrm{pm}$ & 77 & 70 & 1 & 6 & 0 & 7 & 10 \\
\hline $24 \mathrm{hours}$ & 1213 & 1158 & 7 & 46 & 2 & 55 & 4.75 \\
\hline & & & & & & & \\
\hline
\end{tabular}

cars and 18\% error was due to people entering the garage. The "Cars Detected" and "Actual Cars" detected of Table 4.3 are compared and plotted against the "Hour" and shown in Figure 4.10. 
Table 4.3: Day 3 - April 22 to April 23, 2015

\begin{tabular}{|l|c|c|c|c|c|c|c|}
\hline Hour & $\begin{array}{c}\text { Cars } \\
\text { detected }\end{array}$ & $\begin{array}{c}\text { Actual } \\
\text { cars }\end{array}$ & $\begin{array}{c}\text { Golf } \\
\text { Carts }\end{array}$ & $\begin{array}{c}\text { Exiting } \\
\text { Cars }\end{array}$ & People & Error & $\begin{array}{c}\text { Percent } \\
\text { Error }\end{array}$ \\
\hline $5-6 \mathrm{pm}$ & 26 & 19 & 0 & 7 & 0 & 7 & 36.84 \\
\hline $6-7 \mathrm{pm}$ & 35 & 27 & 0 & 7 & 1 & 8 & 29.63 \\
\hline $7-8 \mathrm{pm}$ & 25 & 23 & 0 & 2 & 0 & 2 & 8.70 \\
\hline $8-9 \mathrm{pm}$ & 23 & 22 & 0 & 1 & 0 & 1 & 4.55 \\
\hline $9-10 \mathrm{pm}$ & 23 & 20 & 0 & 1 & 2 & 3 & 15 \\
\hline $10-11 \mathrm{pm}$ & 53 & 47 & 2 & 3 & 1 & 6 & 12.77 \\
\hline $11-12 \mathrm{am}$ & 14 & 14 & 0 & 0 & 0 & 0 & 0 \\
\hline $12-1 \mathrm{am}$ & 15 & 11 & 0 & 1 & 3 & 4 & 36.36 \\
\hline $1-2 \mathrm{am}$ & 7 & 4 & 0 & 2 & 1 & 3 & 75 \\
\hline $2-3 \mathrm{am}$ & 12 & 9 & 1 & 0 & 2 & 3 & 33.33 \\
\hline $3-4 \mathrm{am}$ & 6 & 6 & 0 & 0 & 0 & 0 & 0 \\
\hline $4-5 \mathrm{am}$ & 2 & 2 & 0 & 0 & 0 & 0 & 0 \\
\hline $5-6 \mathrm{am}$ & 2 & 2 & 0 & 0 & 0 & 0 & 0 \\
\hline $6-7 \mathrm{am}$ & 4 & 3 & 0 & 1 & 0 & 1 & 33.33 \\
\hline $7-8 \mathrm{am}$ & 52 & 52 & 0 & 0 & 0 & 0 & 0 \\
\hline $8-9 \mathrm{am}$ & 80 & 78 & 2 & 0 & 0 & 2 & 2.56 \\
\hline $9-10 \mathrm{am}$ & 172 & 170 & 1 & 1 & 0 & 2 & 1.18 \\
\hline $10-11 \mathrm{am}$ & 159 & 158 & 0 & 1 & 0 & 1 & 0.63 \\
\hline $11-12 \mathrm{pm}$ & 82 & 80 & 1 & 1 & 0 & 2 & 2.5 \\
\hline $12-1 \mathrm{pm}$ & 153 & 152 & 1 & 0 & 0 & 1 & 0.66 \\
\hline $1-2 \mathrm{pm}$ & 123 & 120 & 0 & 3 & 0 & 3 & 2.5 \\
\hline $2-3 \mathrm{pm}$ & 56 & 54 & 1 & 1 & 0 & 2 & 3.70 \\
\hline $3-4 \mathrm{pm}$ & 61 & 58 & 2 & 1 & 0 & 3 & 5.17 \\
\hline $4-5 \mathrm{pm}$ & 55 & 54 & 0 & 1 & 0 & 1 & 1.85 \\
\hline $24 \mathrm{hours}$ & 1240 & 1185 & 11 & 34 & 10 & 55 & 4.64 \\
\hline & & & & & & & \\
\hline
\end{tabular}

Table 4.4 shows the data collected from April 23 to April 24, 2015. By the end of 24 hours, there was an error of $7.51 \%$. 20\% of error was due to Golf carts, $69 \%$ of the error was due to exiting cars and $11 \%$ error was due to people entering the garage. The "Cars Detected" and "Actual Cars" detected of Table 4.4 are compared and plotted against the "Hour" and shown in Figure 4.11. 


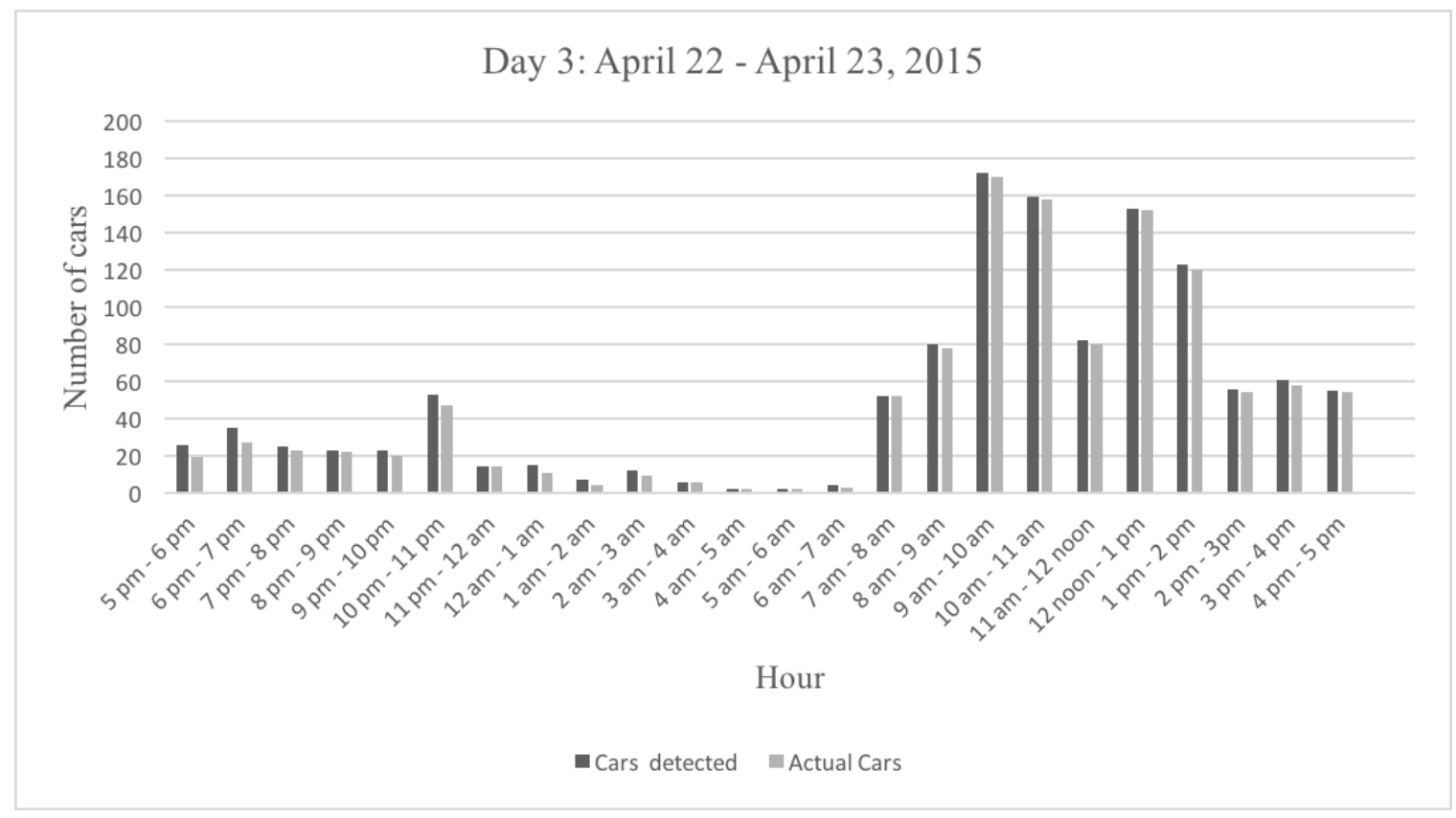

Figure 4.10: Day 3 plot

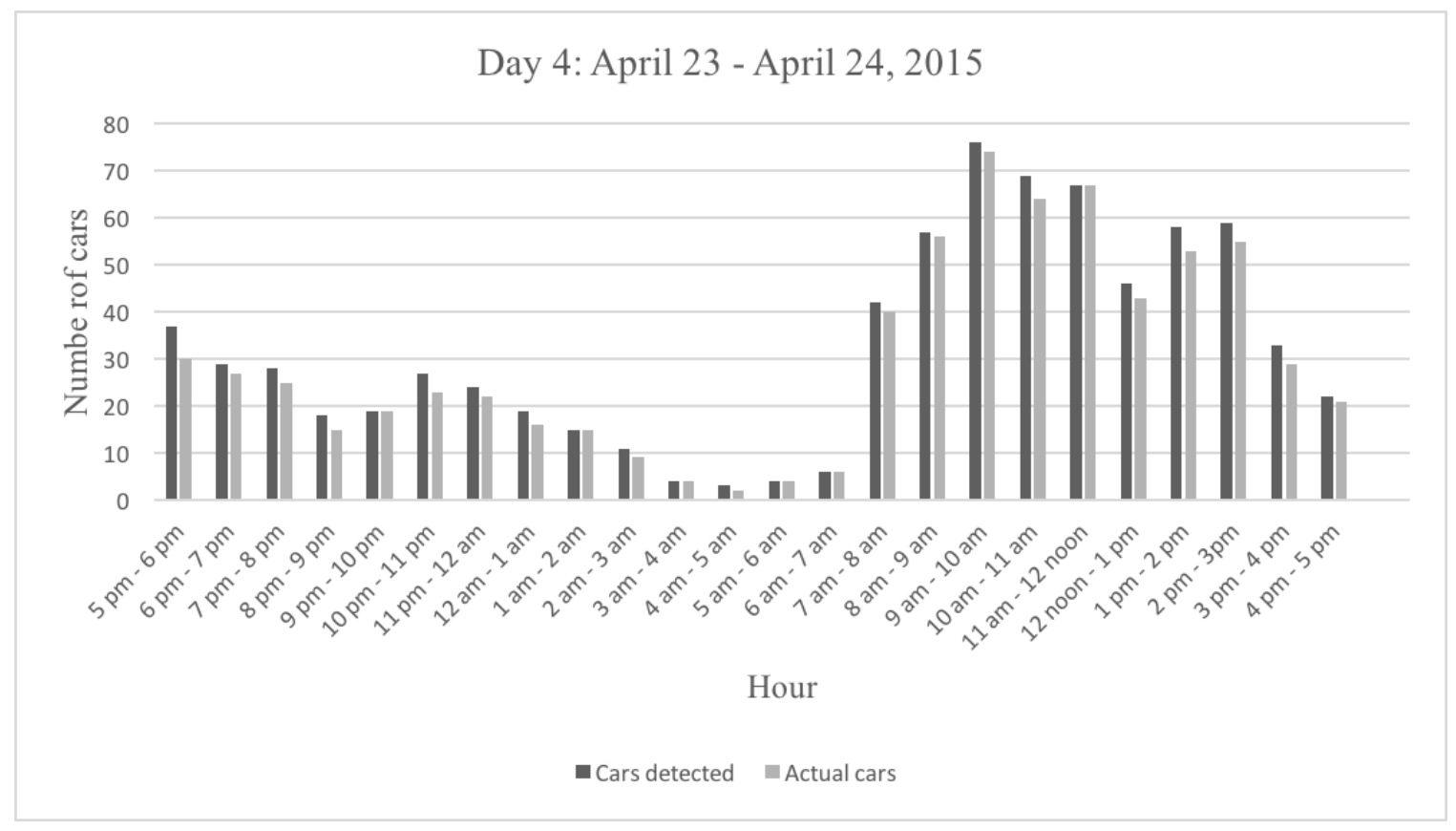

Figure 4.11: Day 4 plot

Table 4.5 shows the data collected from April 24 to April 25, 2015. By the end of 24 hours, there was an error of $8.33 \%$. $9 \%$ of error was due to Golf carts, $63 \%$ of the error was due to exiting 
Table 4.4: Day 4 - April 23 to April 24, 2015

\begin{tabular}{|l|c|c|c|c|c|c|c|}
\hline Hour & $\begin{array}{c}\text { Cars } \\
\text { detected }\end{array}$ & $\begin{array}{c}\text { Actual } \\
\text { cars }\end{array}$ & $\begin{array}{c}\text { Golf } \\
\text { Carts }\end{array}$ & $\begin{array}{c}\text { Exiting } \\
\text { Cars }\end{array}$ & People & Error & $\begin{array}{c}\text { Percent } \\
\text { Error }\end{array}$ \\
\hline $5-6 \mathrm{pm}$ & 37 & 30 & 0 & 7 & 0 & 7 & 23.33 \\
\hline $6-7 \mathrm{pm}$ & 29 & 27 & 0 & 1 & 1 & 2 & 7.40 \\
\hline $7-8 \mathrm{pm}$ & 28 & 25 & 0 & 3 & 0 & 3 & 12 \\
\hline $8-9 \mathrm{pm}$ & 18 & 15 & 0 & 3 & 0 & 3 & 20 \\
\hline $9-10 \mathrm{pm}$ & 19 & 19 & 0 & 0 & 0 & 0 & 0 \\
\hline $10-11 \mathrm{pm}$ & 27 & 23 & 1 & 2 & 1 & 4 & 17.40 \\
\hline $11-12 \mathrm{am}$ & 24 & 22 & 0 & 0 & 2 & 2 & 9.09 \\
\hline $12-1 \mathrm{am}$ & 19 & 16 & 0 & 2 & 1 & 3 & 18.75 \\
\hline $1-2 \mathrm{am}$ & 15 & 15 & 0 & 0 & 0 & 0 & 0 \\
\hline $2-3 \mathrm{am}$ & 11 & 9 & 0 & 2 & 0 & 2 & 22.22 \\
\hline $3-4 \mathrm{am}$ & 4 & 4 & 0 & 0 & 0 & 0 & 0 \\
\hline $4-5 \mathrm{am}$ & 3 & 2 & 1 & 0 & 0 & 1 & 50 \\
\hline $5-6 \mathrm{am}$ & 4 & 4 & 0 & 0 & 0 & 0 & 0 \\
\hline $6-7 \mathrm{am}$ & 6 & 6 & 0 & 0 & 0 & 0 & 0 \\
\hline $7-8 \mathrm{am}$ & 42 & 40 & 0 & 2 & 0 & 2 & 5 \\
\hline $8-9 \mathrm{am}$ & 57 & 56 & 1 & 0 & 0 & 1 & 1.79 \\
\hline $9-10 \mathrm{am}$ & 76 & 74 & 1 & 1 & 0 & 2 & 2.70 \\
\hline $10-11 \mathrm{am}$ & 69 & 64 & 2 & 3 & 0 & 5 & 7.81 \\
\hline $11-12 \mathrm{pm}$ & 67 & 67 & 0 & 0 & 0 & 0 & 0 \\
\hline $12-1 \mathrm{pm}$ & 46 & 43 & 0 & 3 & 0 & 3 & 6.98 \\
\hline $1-2 \mathrm{pm}$ & 58 & 53 & 3 & 1 & 1 & 5 & 9.43 \\
\hline $2-3 \mathrm{pm}$ & 59 & 55 & 1 & 3 & 0 & 4 & 7.27 \\
\hline $3-4 \mathrm{pm}$ & 33 & 29 & 1 & 3 & 0 & 4 & 13.79 \\
\hline $4-5 \mathrm{pm}$ & 22 & 21 & 0 & 1 & 0 & 1 & 4.76 \\
\hline $24 \mathrm{hours}$ & 773 & 719 & 11 & 37 & 6 & 54 & 7.51 \\
\hline & & & & & & & \\
\hline
\end{tabular}

cars and $28 \%$ error was due to people entering the garage. The "Cars Detected" and "Actual Cars" detected of Table 4.5 are compared and plotted against the "Hour" and shown in Figure 4.12.

\subsubsection{Hourly and Peak Hour Times}

This section analyzes the error accumulating hourly and analyzes the system efficiency during peak hour times. Tables 4.6 - 4.10 show the error accumulating for each hour over 24 hours. 
Table 4.5: Day 5 - April 24 to April 25, 2015

\begin{tabular}{|l|c|c|c|c|c|c|c|}
\hline Hour & $\begin{array}{c}\text { Cars } \\
\text { detected }\end{array}$ & $\begin{array}{c}\text { Actual } \\
\text { cars }\end{array}$ & $\begin{array}{c}\text { Golf } \\
\text { Carts }\end{array}$ & $\begin{array}{c}\text { Exiting } \\
\text { Cars }\end{array}$ & People & Error & $\begin{array}{c}\text { Percent } \\
\text { Error }\end{array}$ \\
\hline $5-6 \mathrm{pm}$ & 18 & 18 & 0 & 0 & 0 & 0 & 0 \\
\hline $6-7 \mathrm{pm}$ & 15 & 12 & 0 & 1 & 2 & 3 & 25 \\
\hline $7-8 \mathrm{pm}$ & 14 & 11 & 1 & 2 & 0 & 3 & 27.27 \\
\hline $8-9 \mathrm{pm}$ & 17 & 17 & 0 & 0 & 0 & 0 & 0 \\
\hline $9-10 \mathrm{pm}$ & 21 & 19 & 0 & 2 & 0 & 2 & 10.53 \\
\hline $10-11 \mathrm{pm}$ & 14 & 12 & 1 & 1 & 0 & 2 & 16.67 \\
\hline $11-12 \mathrm{am}$ & 21 & 19 & 0 & 1 & 1 & 2 & 10.53 \\
\hline $12-1 \mathrm{am}$ & 10 & 10 & 0 & 0 & 0 & 0 & 0 \\
\hline $1-2 \mathrm{am}$ & 14 & 12 & 0 & 0 & 2 & 2 & 16.67 \\
\hline $2-3 \mathrm{am}$ & 7 & 7 & 0 & 0 & 0 & 0 & 0 \\
\hline $3-4 \mathrm{am}$ & 12 & 12 & 0 & 0 & 0 & 0 & 0 \\
\hline $4-5 \mathrm{am}$ & 1 & 1 & 0 & 0 & 0 & 0 & 0 \\
\hline $5-6 \mathrm{am}$ & 1 & 1 & 0 & 0 & 0 & 0 & 0 \\
\hline $6-7 \mathrm{am}$ & 13 & 13 & 0 & 0 & 0 & 0 & 0 \\
\hline $7-8 \mathrm{am}$ & 9 & 8 & 0 & 1 & 0 & 1 & 12.5 \\
\hline $8-9 \mathrm{am}$ & 13 & 12 & 0 & 1 & 0 & 1 & 8.33 \\
\hline $9-10 \mathrm{am}$ & 33 & 33 & 0 & 0 & 0 & 0 & 0 \\
\hline $10-11 \mathrm{am}$ & 16 & 14 & 0 & 1 & 1 & 2 & 14.28 \\
\hline $11-12 \mathrm{pm}$ & 35 & 33 & 0 & 2 & 0 & 2 & 6.06 \\
\hline $12-1 \mathrm{pm}$ & 29 & 26 & 1 & 2 & 0 & 3 & 11.54 \\
\hline $1-2 \mathrm{pm}$ & 21 & 20 & 0 & 0 & 1 & 1 & 5 \\
\hline $2-3 \mathrm{pm}$ & 38 & 35 & 0 & 3 & 0 & 3 & 8.57 \\
\hline $3-4 \mathrm{pm}$ & 20 & 19 & 0 & 1 & 0 & 1 & 5.26 \\
\hline $4-5 \mathrm{pm}$ & 24 & 20 & 0 & 2 & 2 & 4 & 20 \\
\hline $24 \mathrm{hours}$ & 416 & 384 & 3 & 20 & 9 & 32 & 8.33 \\
\hline & & & & & & & \\
\hline
\end{tabular}

Table 4.6 shows the data collected from April 15 to April 16, 2015. Here the error started with an error of $11.76 \%$ and accumulated over the time. By the end of the test, the accumulated error decreased to $4.56 \%$. 


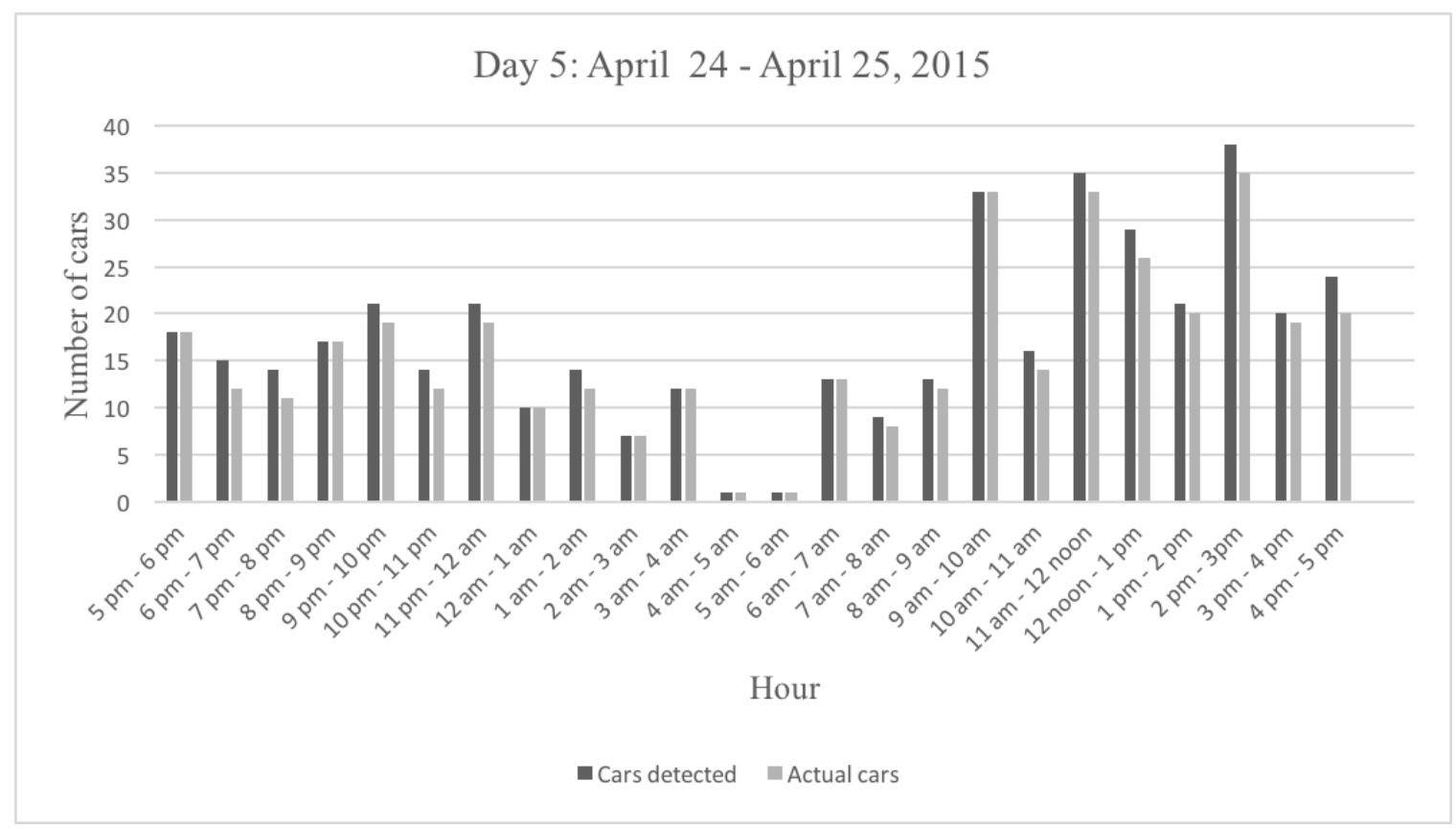

Figure 4.12: Day 5 plot

\subsubsection{Days}

This section discusses the average error for trials conducted for five days. Table 4.11 shows the average error percentage occurred over a period of time and Table 4.12 shows the average error occurred over five days.

The total number of cars detected were 4,947 out of which 4,694 were actual cars. We can see that $70 \%$ of the error is due to exiting cars. This is because the sensor is installed over the entrance lane however the cars straddled over entrance/exit lanes. This error can be removed by separating the entry and exiting pathways by a medium so that cars stay in their lanes.

\subsection{Chapter Summary}

This chapter presented the experimental set up used to test the selected sensor, calibration of the sensor, and initial feasibility test results. After initial feasibility tests, plots (Figure 4.2 and Figure 
Table 4.6: Day 1 (accumulated) - April 15 to April 16, 2015

\begin{tabular}{|l|c|c|c|c|c|c|c|}
\hline Hour & $\begin{array}{c}\text { Cars } \\
\text { detected }\end{array}$ & $\begin{array}{c}\text { Actual } \\
\text { cars }\end{array}$ & $\begin{array}{c}\text { Golf } \\
\text { Carts }\end{array}$ & $\begin{array}{c}\text { Exiting } \\
\text { Cars }\end{array}$ & People & Error & $\begin{array}{c}\text { Percent } \\
\text { Error }\end{array}$ \\
\hline $6.40 \mathrm{pm}-7.40 \mathrm{pm}$ & 19 & 17 & 2 & 0 & 0 & 2 & 11.76 \\
\hline $6.40 \mathrm{pm}-8.40 \mathrm{pm}$ & 38 & 33 & 3 & 2 & 0 & 5 & 15.15 \\
\hline $6.40 \mathrm{pm}-9.40 \mathrm{pm}$ & 58 & 50 & 3 & 5 & 0 & 8 & 16 \\
\hline $6.40 \mathrm{pm}-10.40 \mathrm{pm}$ & 92 & 78 & 4 & 8 & 2 & 14 & 17.95 \\
\hline $6.40 \mathrm{pm}-11.40 \mathrm{pm}$ & 118 & 101 & 5 & 10 & 2 & 17 & 16.83 \\
\hline $6.40 \mathrm{pm}-12.40 \mathrm{am}$ & 137 & 119 & 5 & 11 & 2 & 18 & 15.13 \\
\hline $6.40 \mathrm{pm}-1.40 \mathrm{am}$ & 153 & 132 & 5 & 14 & 2 & 21 & 15.91 \\
\hline $6.40 \mathrm{pm}-2.40 \mathrm{am}$ & 161 & 140 & 5 & 14 & 2 & 21 & 15 \\
\hline $6.40 \mathrm{pm}-3.40 \mathrm{am}$ & 169 & 148 & 5 & 14 & 2 & 21 & 14.18 \\
\hline $6.40 \mathrm{pm}-4.40 \mathrm{am}$ & 170 & 149 & 5 & 14 & 2 & 21 & 14.09 \\
\hline $6.40 \mathrm{pm}-5.40 \mathrm{am}$ & 171 & 150 & 5 & 14 & 2 & 21 & 14 \\
\hline $6.40 \mathrm{pm}-6.40 \mathrm{am}$ & 178 & 155 & 6 & 15 & 2 & 23 & 14.84 \\
\hline $6.40 \mathrm{pm}-7.40 \mathrm{am}$ & 209 & 186 & 6 & 15 & 2 & 23 & 12.36 \\
\hline $6.40 \mathrm{pm}-8.40 \mathrm{am}$ & 291 & 267 & 6 & 15 & 3 & 24 & 8.99 \\
\hline $6.40 \mathrm{pm}-9.40 \mathrm{am}$ & 458 & 433 & 6 & 15 & 4 & 25 & 5.77 \\
\hline $6.40 \mathrm{pm}-10.40 \mathrm{am}$ & 583 & 557 & 6 & 16 & 4 & 26 & 4.67 \\
\hline $6.40 \mathrm{pm}-11.40 \mathrm{am}$ & 733 & 705 & 6 & 18 & 4 & 28 & 3.97 \\
\hline $6.40 \mathrm{pm}-12.40 \mathrm{pm}$ & 893 & 862 & 7 & 20 & 4 & 31 & 3.60 \\
\hline $6.40 \mathrm{pm}-1.40 \mathrm{pm}$ & 994 & 960 & 8 & 22 & 4 & 34 & 3.54 \\
\hline $6.40 \mathrm{pm}-2.40 \mathrm{pm}$ & 1084 & 1045 & 11 & 24 & 4 & 39 & 3.73 \\
\hline $6.40 \mathrm{pm}-3.40 \mathrm{pm}$ & 1149 & 1107 & 12 & 26 & 4 & 42 & 3.79 \\
\hline $6.40 \mathrm{pm}-4.40 \mathrm{pm}$ & 1203 & 1153 & 12 & 31 & 7 & 50 & 4.34 \\
\hline $6.40 \mathrm{pm}-5.40 \mathrm{pm}$ & 1272 & 1216 & 12 & 37 & 7 & 56 & 4.61 \\
\hline $6.40 \mathrm{pm}-6.40 \mathrm{pm}$ & 1305 & 1248 & 12 & 38 & 7 & 57 & 4.56 \\
\hline
\end{tabular}

4.3) were drawn, logic to detect the vehicle was developed, more experiments were conducted to debug the system. Then, the system was deployed at the West entrance of Richard Beard Garage, and field trials were performed for five days continuously. Results of each trial are provided in tabular form showing the percentage error for each hour, percentage error accumulated over the day, percentage error of five days, and percentage error accumulated over five days. Error cases of golf carts, exiting cars, and people are also shown to better understand the error. Also, a counter measure to reduce the error has been proposed. 
Table 4.7: Day 2 (accumulated) - April 21 to April 22, 2015

\begin{tabular}{|l|c|c|c|c|c|c|c|}
\hline Hour & $\begin{array}{c}\text { Cars } \\
\text { detected }\end{array}$ & $\begin{array}{c}\text { Actual } \\
\text { cars }\end{array}$ & $\begin{array}{c}\text { Golf } \\
\text { Carts }\end{array}$ & $\begin{array}{c}\text { Exiting } \\
\text { Cars }\end{array}$ & People & Error & $\begin{array}{c}\text { Percent } \\
\text { Error }\end{array}$ \\
\hline $4 \mathrm{pm}-5 \mathrm{pm}$ & 70 & 65 & 0 & 5 & 0 & 5 & 7.70 \\
\hline $4 \mathrm{pm}-6 \mathrm{pm}$ & 105 & 96 & 0 & 9 & 0 & 9 & 9.38 \\
\hline $4 \mathrm{pm}-7 \mathrm{pm}$ & 136 & 126 & 0 & 10 & 0 & 10 & 7.94 \\
\hline $4 \mathrm{pm}-8 \mathrm{pm}$ & 159 & 144 & 1 & 14 & 0 & 15 & 10.42 \\
\hline $4 \mathrm{pm}-9 \mathrm{pm}$ & 191 & 173 & 1 & 17 & 0 & 18 & 10.40 \\
\hline $4 \mathrm{pm}-10 \mathrm{pm}$ & 211 & 187 & 1 & 23 & 0 & 24 & 12.83 \\
\hline $4 \mathrm{pm}-11 \mathrm{pm}$ & 235 & 209 & 1 & 24 & 1 & 26 & 12.44 \\
\hline $4 \mathrm{pm}-12 \mathrm{am}$ & 262 & 233 & 1 & 27 & 1 & 29 & 12.45 \\
\hline $4 \mathrm{pm}-1 \mathrm{am}$ & 275 & 246 & 1 & 27 & 1 & 29 & 11.79 \\
\hline $4 \mathrm{pm}-2 \mathrm{am}$ & 288 & 258 & 1 & 28 & 1 & 30 & 11.63 \\
\hline $4 \mathrm{pm}-3 \mathrm{am}$ & 295 & 265 & 1 & 28 & 1 & 30 & 11.32 \\
\hline $4 \mathrm{pm}-4 \mathrm{am}$ & 300 & 270 & 1 & 28 & 1 & 30 & 11.11 \\
\hline $4 \mathrm{pm}-5 \mathrm{am}$ & 303 & 273 & 1 & 28 & 1 & 30 & 10.99 \\
\hline $4 \mathrm{pm}-6$ am & 306 & 276 & 1 & 28 & 1 & 30 & 10.87 \\
\hline $4 \mathrm{pm}-7$ am & 319 & 288 & 1 & 29 & 1 & 31 & 10.76 \\
\hline $4 \mathrm{pm}-8$ am & 400 & 368 & 1 & 30 & 1 & 32 & 8.70 \\
\hline $4 \mathrm{pm}-9$ am & 504 & 471 & 2 & 30 & 1 & 33 & 7 \\
\hline $4 \mathrm{pm}-10 \mathrm{am}$ & 644 & 608 & 3 & 32 & 1 & 36 & 5.92 \\
\hline $4 \mathrm{pm}-11$ am & 799 & 761 & 4 & 33 & 1 & 38 & 4.99 \\
\hline $4 \mathrm{pm}-12 \mathrm{pm}$ & 871 & 831 & 4 & 35 & 1 & 40 & 4.81 \\
\hline $4 \mathrm{pm}-1 \mathrm{pm}$ & 974 & 932 & 4 & 36 & 2 & 42 & 4.51 \\
\hline $4 \mathrm{pm}-2 \mathrm{pm}$ & 1079 & 1033 & 5 & 39 & 2 & 46 & 4.45 \\
\hline $4 \mathrm{pm}-3 \mathrm{pm}$ & 1136 & 1088 & 6 & 40 & 2 & 48 & 4.41 \\
\hline $4 \mathrm{pm}-4 \mathrm{pm}$ & 1213 & 1158 & 7 & 46 & 2 & 55 & 4.75 \\
\hline
\end{tabular}


Table 4.8: Day 3 (accumulated)- April 22 to April 23, 2015

\begin{tabular}{|l|c|c|c|c|c|c|c|}
\hline Hour & $\begin{array}{c}\text { Cars } \\
\text { detected }\end{array}$ & $\begin{array}{c}\text { Actual } \\
\text { cars }\end{array}$ & $\begin{array}{c}\text { Golf } \\
\text { Carts }\end{array}$ & $\begin{array}{c}\text { Exiting } \\
\text { Cars }\end{array}$ & People & Error & $\begin{array}{c}\text { Percent } \\
\text { Error }\end{array}$ \\
\hline 5 pm-6 pm & 26 & 19 & 0 & 7 & 0 & 7 & 36.84 \\
\hline 5 pm-7 pm & 61 & 46 & 0 & 14 & 1 & 15 & 32.61 \\
\hline 5 pm-8 pm & 86 & 69 & 0 & 16 & 1 & 17 & 24.64 \\
\hline 5 pm-9 pm & 109 & 91 & 0 & 17 & 1 & 18 & 19.78 \\
\hline 5 pm-10 pm & 132 & 111 & 0 & 18 & 3 & 21 & 18.92 \\
\hline 5 pm-11 pm & 185 & 158 & 2 & 21 & 4 & 27 & 17.09 \\
\hline 5 pm-12 am & 199 & 172 & 2 & 21 & 4 & 27 & 15.70 \\
\hline 5 pm-1 am & 214 & 163 & 2 & 22 & 7 & 31 & 16.94 \\
\hline 5 pm-2 am & 221 & 187 & 2 & 24 & 8 & 34 & 18.18 \\
\hline 5 pm-3 am & 233 & 196 & 3 & 24 & 10 & 37 & 18.88 \\
\hline 5 pm-4 am & 239 & 202 & 3 & 24 & 10 & 37 & 18.32 \\
\hline 5 pm-5 am & 241 & 204 & 3 & 24 & 10 & 37 & 18.14 \\
\hline 5 pm-6 am & 243 & 206 & 3 & 24 & 10 & 37 & 17.96 \\
\hline 5 pm-7 am & 247 & 209 & 3 & 25 & 10 & 38 & 18.18 \\
\hline 5 pm-8 am & 299 & 261 & 3 & 25 & 10 & 38 & 14.56 \\
\hline 5 pm-9 am & 379 & 339 & 5 & 25 & 10 & 40 & 11.80 \\
\hline 5 pm-10 am & 551 & 509 & 6 & 26 & 10 & 42 & 8.25 \\
\hline 5 pm-11 am & 710 & 667 & 6 & 27 & 10 & 43 & 6.45 \\
\hline 5 pm-12 pm & 792 & 747 & 7 & 28 & 10 & 45 & 6.02 \\
\hline 5 pm-1 pm & 945 & 899 & 8 & 28 & 10 & 46 & 5.12 \\
\hline 5 pm-2 pm & 1068 & 1019 & 8 & 31 & 10 & 49 & 4.81 \\
\hline 5 pm-3 pm & 1124 & 1073 & 9 & 32 & 10 & 51 & 4.75 \\
\hline 5 pm-4 pm & 1185 & 1131 & 11 & 33 & 10 & 54 & 4.77 \\
\hline 5 pm-5 pm & 1240 & 1185 & 11 & 34 & 10 & 55 & 4.64 \\
\hline
\end{tabular}


Table 4.9: Day 4 (accumulated) - April 23 to April 24, 2015

\begin{tabular}{|l|c|c|c|c|c|c|c|}
\hline Hour & $\begin{array}{c}\text { Cars } \\
\text { detected }\end{array}$ & $\begin{array}{c}\text { Actual } \\
\text { cars }\end{array}$ & $\begin{array}{c}\text { Golf } \\
\text { Carts }\end{array}$ & $\begin{array}{c}\text { Exiting } \\
\text { Cars }\end{array}$ & People & Error & $\begin{array}{c}\text { Percent } \\
\text { Error }\end{array}$ \\
\hline 5 pm-6 pm & 37 & 30 & 0 & 7 & 0 & 7 & 23.33 \\
\hline 5 pm-7 pm & 66 & 57 & 0 & 8 & 1 & 9 & 15.79 \\
\hline 5 pm-8 pm & 94 & 82 & 0 & 11 & 1 & 12 & 14.63 \\
\hline 5 pm-9 pm & 112 & 97 & 0 & 14 & 1 & 15 & 15.46 \\
\hline 5 pm-10 pm & 131 & 116 & 0 & 14 & 1 & 15 & 12.93 \\
\hline 5 pm-11 pm & 158 & 139 & 1 & 16 & 2 & 19 & 13.67 \\
\hline 5 pm-12 am & 182 & 161 & 1 & 16 & 4 & 21 & 13.04 \\
\hline 5 pm-1 am & 201 & 177 & 1 & 18 & 5 & 24 & 13.56 \\
\hline 5 pm-2 am & 216 & 192 & 1 & 18 & 5 & 24 & 12.50 \\
\hline 5 pm-3 am & 227 & 201 & 1 & 20 & 5 & 26 & 12.94 \\
\hline 5 pm-4 am & 231 & 205 & 1 & 20 & 5 & 26 & 12.68 \\
\hline 5 pm-5 am & 234 & 207 & 2 & 20 & 5 & 27 & 13.04 \\
\hline 5 pm-6 am & 238 & 211 & 2 & 20 & 5 & 27 & 12.80 \\
\hline 5 pm-7 am & 244 & 217 & 2 & 20 & 5 & 27 & 12.44 \\
\hline 5 pm-8 am & 286 & 257 & 2 & 22 & 5 & 29 & 11.28 \\
\hline 5 pm-9 am & 343 & 313 & 3 & 22 & 5 & 30 & 9.58 \\
\hline 5 pm-10 am & 419 & 387 & 4 & 23 & 5 & 32 & 8.27 \\
\hline 5 pm-11 am & 488 & 451 & 6 & 26 & 5 & 37 & 8.20 \\
\hline 5 pm-12 pm & 555 & 518 & 6 & 26 & 5 & 37 & 7.14 \\
\hline 5 pm-1 pm & 601 & 561 & 6 & 29 & 5 & 40 & 7.13 \\
\hline 5 pm-2 pm & 659 & 614 & 9 & 30 & 6 & 45 & 7.33 \\
\hline 5 pm-3 pm & 718 & 669 & 10 & 33 & 6 & 49 & 7.32 \\
\hline 5 pm-4 pm & 751 & 698 & 11 & 36 & 6 & 53 & 7.59 \\
\hline 5 pm-5 pm & 773 & 719 & 11 & 37 & 6 & 54 & 7.51 \\
\hline
\end{tabular}


Table 4.10: Day 5 (accumulated) - April 24 to April 25, 2015

\begin{tabular}{|l|c|c|c|c|c|c|c|}
\hline Hour & $\begin{array}{c}\text { Cars } \\
\text { detected }\end{array}$ & $\begin{array}{c}\text { Actual } \\
\text { cars }\end{array}$ & $\begin{array}{c}\text { Golf } \\
\text { Carts }\end{array}$ & $\begin{array}{c}\text { Exiting } \\
\text { Cars }\end{array}$ & People & Error & $\begin{array}{c}\text { Percent } \\
\text { Error }\end{array}$ \\
\hline $5 \mathrm{pm}-6 \mathrm{pm}$ & 18 & 18 & 0 & 0 & 0 & 0 & 0 \\
\hline $5 \mathrm{pm}-7 \mathrm{pm}$ & 33 & 30 & 0 & 1 & 2 & 3 & 10 \\
\hline $5 \mathrm{pm}-8 \mathrm{pm}$ & 47 & 41 & 1 & 3 & 2 & 6 & 14.63 \\
\hline $5 \mathrm{pm}-9 \mathrm{pm}$ & 64 & 58 & 1 & 3 & 2 & 6 & 10.34 \\
\hline $5 \mathrm{pm}-10 \mathrm{pm}$ & 85 & 77 & 1 & 5 & 2 & 8 & 10.39 \\
\hline $5 \mathrm{pm}-11 \mathrm{pm}$ & 99 & 89 & 2 & 6 & 2 & 10 & 11.24 \\
\hline $5 \mathrm{pm}-12 \mathrm{am}$ & 120 & 108 & 2 & 7 & 3 & 12 & 11.11 \\
\hline $5 \mathrm{pm}-1 \mathrm{am}$ & 130 & 113 & 2 & 7 & 3 & 12 & 10.17 \\
\hline $5 \mathrm{pm}-2 \mathrm{am}$ & 144 & 130 & 2 & 7 & 5 & 14 & 10.77 \\
\hline $5 \mathrm{pm}-3 \mathrm{am}$ & 151 & 137 & 2 & 7 & 5 & 14 & 10.21 \\
\hline $5 \mathrm{pm}-4 \mathrm{am}$ & 163 & 149 & 2 & 7 & 5 & 14 & 9.40 \\
\hline $5 \mathrm{pm}-5 \mathrm{am}$ & 164 & 150 & 2 & 7 & 5 & 14 & 9.33 \\
\hline $5 \mathrm{pm}-6 \mathrm{am}$ & 165 & 151 & 2 & 7 & 5 & 14 & 9.27 \\
\hline $5 \mathrm{pm}-7 \mathrm{am}$ & 178 & 164 & 2 & 7 & 5 & 14 & 8.54 \\
\hline $5 \mathrm{pm}-8 \mathrm{am}$ & 187 & 172 & 2 & 8 & 5 & 15 & 8.72 \\
\hline $5 \mathrm{pm}-9$ am & 200 & 184 & 2 & 9 & 5 & 16 & 8.70 \\
\hline $5 \mathrm{pm}-10 \mathrm{am}$ & 233 & 217 & 2 & 9 & 5 & 16 & 7.37 \\
\hline $5 \mathrm{pm}-11 \mathrm{am}$ & 249 & 231 & 2 & 10 & 6 & 18 & 7.8 \\
\hline $5 \mathrm{pm}-12 \mathrm{pm}$ & 284 & 264 & 2 & 12 & 6 & 20 & 7.58 \\
\hline $5 \mathrm{pm}-1 \mathrm{pm}$ & 313 & 290 & 3 & 14 & 6 & 23 & 7.93 \\
\hline $5 \mathrm{pm}-2 \mathrm{pm}$ & 334 & 310 & 3 & 14 & 7 & 24 & 7.74 \\
\hline $5 \mathrm{pm}-3 \mathrm{pm}$ & 372 & 345 & 3 & 17 & 7 & 27 & 7.83 \\
\hline $5 \mathrm{pm}-4 \mathrm{pm}$ & 392 & 364 & 3 & 18 & 7 & 28 & 7.70 \\
\hline $5 \mathrm{pm}-5 \mathrm{pm}$ & 416 & 384 & 3 & 20 & 9 & 32 & 8.33 \\
\hline
\end{tabular}

Table 4.11: Average error for five days

\begin{tabular}{|l|c|c|c|c|c|c|c|}
\hline Days & $\begin{array}{c}\text { Cars } \\
\text { detected }\end{array}$ & $\begin{array}{c}\text { Actual } \\
\text { cars }\end{array}$ & $\begin{array}{c}\text { Golf } \\
\text { Carts }\end{array}$ & $\begin{array}{c}\text { Exiting } \\
\text { Cars }\end{array}$ & People & Error & $\begin{array}{c}\text { Percent } \\
\text { Error }\end{array}$ \\
\hline Day 1 & 1305 & 1248 & 12 & 38 & 7 & 57 & 4.56 \\
\hline Day 2 & 1213 & 1158 & 7 & 46 & 2 & 55 & 4.75 \\
\hline Day 3 & 1240 & 1185 & 11 & 34 & 10 & 55 & 4.64 \\
\hline Day 4 & 773 & 719 & 11 & 37 & 6 & 54 & 7.51 \\
\hline Day 5 & 416 & 384 & 3 & 20 & 9 & 32 & 8.33 \\
\hline 5 days & 4947 & 4694 & 44 & 175 & 34 & 253 & 5.39 \\
\hline
\end{tabular}


Table 4.12: Average error accumulated for five days

\begin{tabular}{|l|c|c|c|c|c|c|c|}
\hline Days & $\begin{array}{c}\text { Cars } \\
\text { detected }\end{array}$ & $\begin{array}{c}\text { Actual } \\
\text { cars }\end{array}$ & $\begin{array}{c}\text { Golf } \\
\text { Carts }\end{array}$ & $\begin{array}{c}\text { Exiting } \\
\text { Cars }\end{array}$ & People & Error & $\begin{array}{c}\text { Percent } \\
\text { Error }\end{array}$ \\
\hline Day 1 & 1305 & 1248 & 12 & 38 & 7 & 57 & 4.56 \\
\hline Day 2 & 2518 & 2406 & 19 & 84 & 9 & 112 & 4.65 \\
\hline Day 3 & 3758 & 3591 & 30 & 118 & 19 & 167 & 4.65 \\
\hline Day 4 & 4531 & 4310 & 41 & 155 & 25 & 221 & 5.13 \\
\hline Day 5 & 4947 & 4694 & 44 & 175 & 34 & 253 & 5.39 \\
\hline
\end{tabular}




\section{CHAPTER 5 : CONCLUSION AND FUTURE WORK}

We draw conclusion and outline the future work. Future work proposes vehicle space availability feature, which can help the driver to know location of the available parking spot after entering the garage. We also propose installation of the system on each floor of Richard Beard Garage to determine the number of parking spots available on each floor.

\subsection{Conclusion}

The vehicle count feature monitors overall count of the parking lot in real time. This system can help the drivers to know the available number of parking spaces before entering the garage. The test results show that the system is accurate in the field. Moreover, the proposed parking guidance system is easy to install because of sensor's small size and low cost. Initially, the challenging task was to select a reliable sensor for this application, which was overcome by a thorough review of sensor technologies. Compared to other technologies, this system does not require installation of sensors into pavements and maintenance. Also, the system works in any weather condition. For

this reason, it is suitable for all kinds of parking areas. In the future, the Arduino processor can be replaced by a PCB design using ATmega328 processor that can further reduce the cost of the system. 


\section{$5.2 \quad$ Future Work}

The vehicle space availability indicator can be an add-on feature to the system. It is simple to indicate if there is a vehicle or not in a particular parking spot using the logic developed to detect a vehicle. This feature needs some additional logic to glow red or green lights. The processor glows red to indicate an occupied spot and green to indicate an available spot.

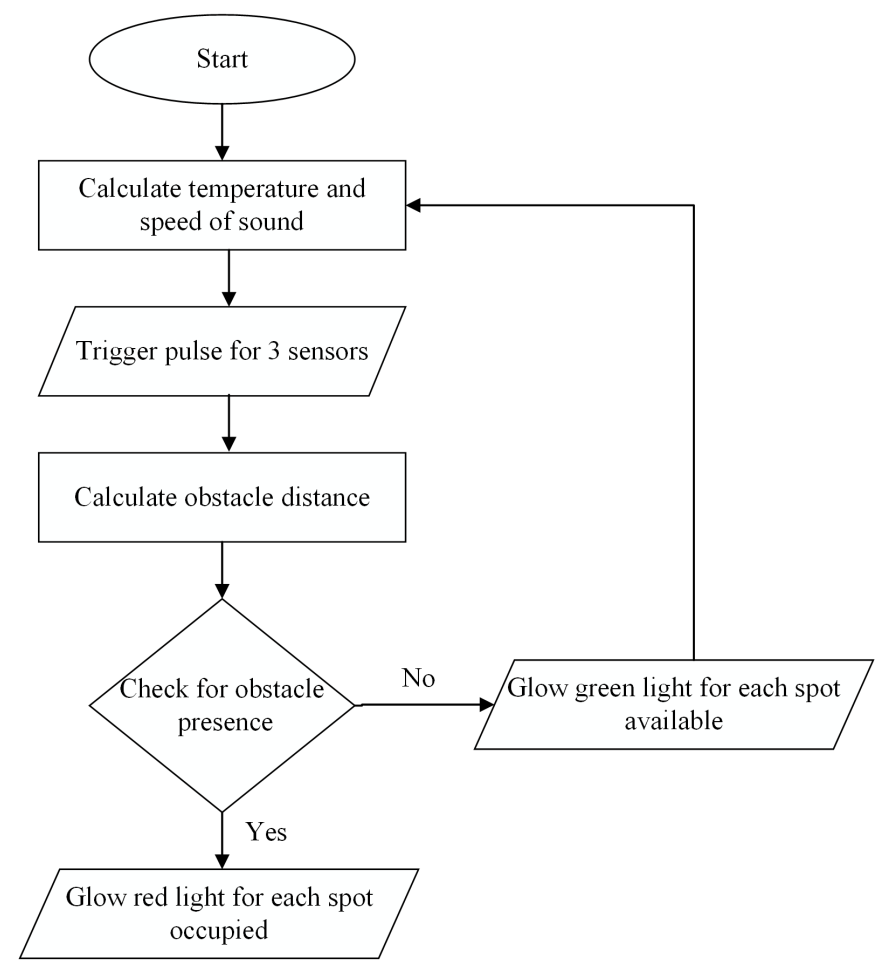

Figure 5.1: Flowchart of the logic to detect parking space availability

Figure 5.1 shows the flowchart of logic involved in indicating spots available. A single processor can monitor three parking spots using three ultrasonic sensors, three green lights, and three red lights. Initially, the processor calculates obstacle distance by triggering pulses to all three sensors. Then, it checks for an obstacle by triggering more pulses. When a vehicle occupies the parking space, the obstacle height is calculated by subtracting new obstacle distance from the maximum range. The 
obstacle height is compared with the minimum threshold height of a vehicle. If the obstacle height is less than minimum obstacle height, then it is an empty spot/available spot, and a green light glows. If greater, then it is an occupied spot and a red light glows. The loop repeats for every two milliseconds to check for an obstacle. Number of available spots on each floor can be known by installing the system at each entrance/exit of each floor. If the system is installed at each floor, it can give us number of cars that have exited and entered each floor. This way, an overall count of each floor can be maintained. 


\section{REFERENCES}

[1] Axis Communications. AXIS Q1614 network camera data sheet. http://www.axis.com/files/ manuals/um_q1614_58675r1_en_1407.pdf.

[2] Elec Freaks. Ultrasonic ranging module HC - SR04. http://www.electroschematics.com/ wp-content/uploads/2013/07/HC-SR04-datasheet-version-2.pdf.

[3] E. Polycarpou, L. Lambrinos, and E. Protopapadakis. Smart parking solutions for urban areas. In World of Wireless, Mobile and Multimedia Networks (WoWMoM), 2013 IEEE 14th International Symposium and Workshops on a, pages 1-6, June 2013.

[4] Y. Geng and C.G. Cassandras. A new "smart parking" system infrastructure and implementation. Procedia-Social and Behavioral Sciences, 54:1278-1287, 2012.

[5] R. Vishnubhotla, P.S. Rao, A. Ladha, S. Kadiyala, A. Narmada, B. Ronanki, and S. Illapakurthi. Zigbee based multi-level parking vacancy monitoring system. In Electro/Information Technology (EIT), 2010 IEEE International Conference on, pages 1-4, May 2010.

[6] G. Revathi and V.R.S. Dhulipala. Smart parking systems and sensors: A survey. In Computing, Communication and Applications (ICCCA), 2012 International Conference on, pages 1-5, Feb 2012.

[7] S. V. Reve and S. Choudhri. Management of car parking system using wireless sensor network. International Journal of Emerging Technology and Advanced Engineering, 2:232-268, July 2012. 
[8] M. Patil and N. V. Bhonge. Parking guidance and information system using RFID and Zigbee. International Journal of Engineering Research and Technology (IJERT), 2:2490-2493, April 2013.

[9] A. Kianpisheh, N. Mustaffa, P. Limtrairut, and P. Keikhosrokiani. Smart parking system (SPS) architecture using ultrasonic detector. International Journal of Software Engineering and Its Applications, 6(3):55-58, 2012.

[10] W. Atmadja, J. Yosafat, R.A. Setiawan, and I.I. Irendy. Parking guidance system based on real time operating system. In Industrial Automation, Information and Communications Technology (IAICT), 2014 International Conference on, pages 5-8, Aug 2014.

[11] S. Shaheen, C.J. Rodier, and C. Kemmerer. Smart parking management field test: A bay area rapid transit (bart) district parking demonstration. Institute of Transportation Studies, 2005.

[12] M.Y. Aalsalem, W.Z. Khan, and K.M. Dhabbah. An automated vehicle parking monitoring and management system using ANPR cameras. In Advanced Communication Technology (ICACT), 2015 17th International Conference on, pages 706-710, July 2015. 


\section{APPENDIX A: ARDUINO SOURCE CODE}

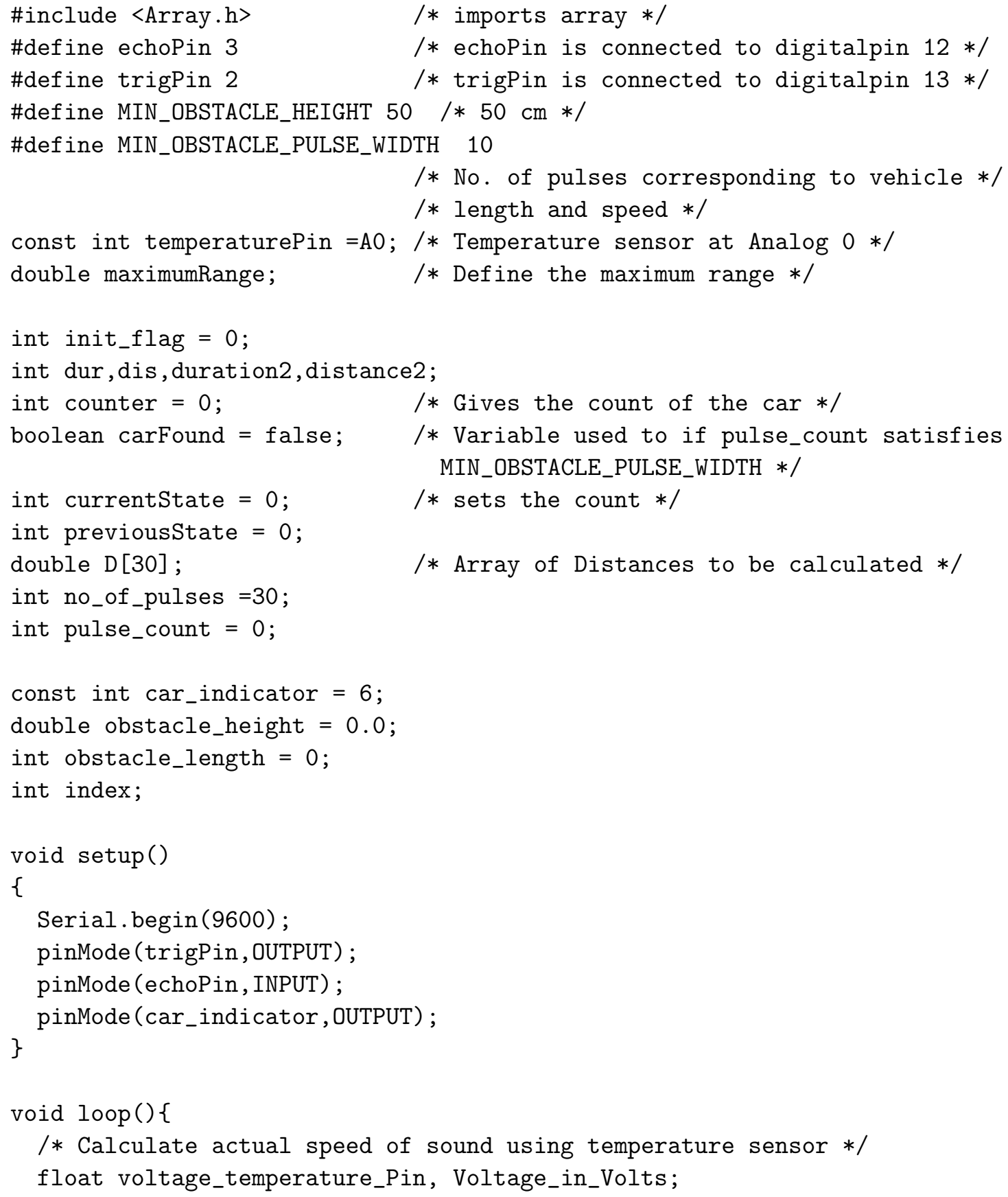




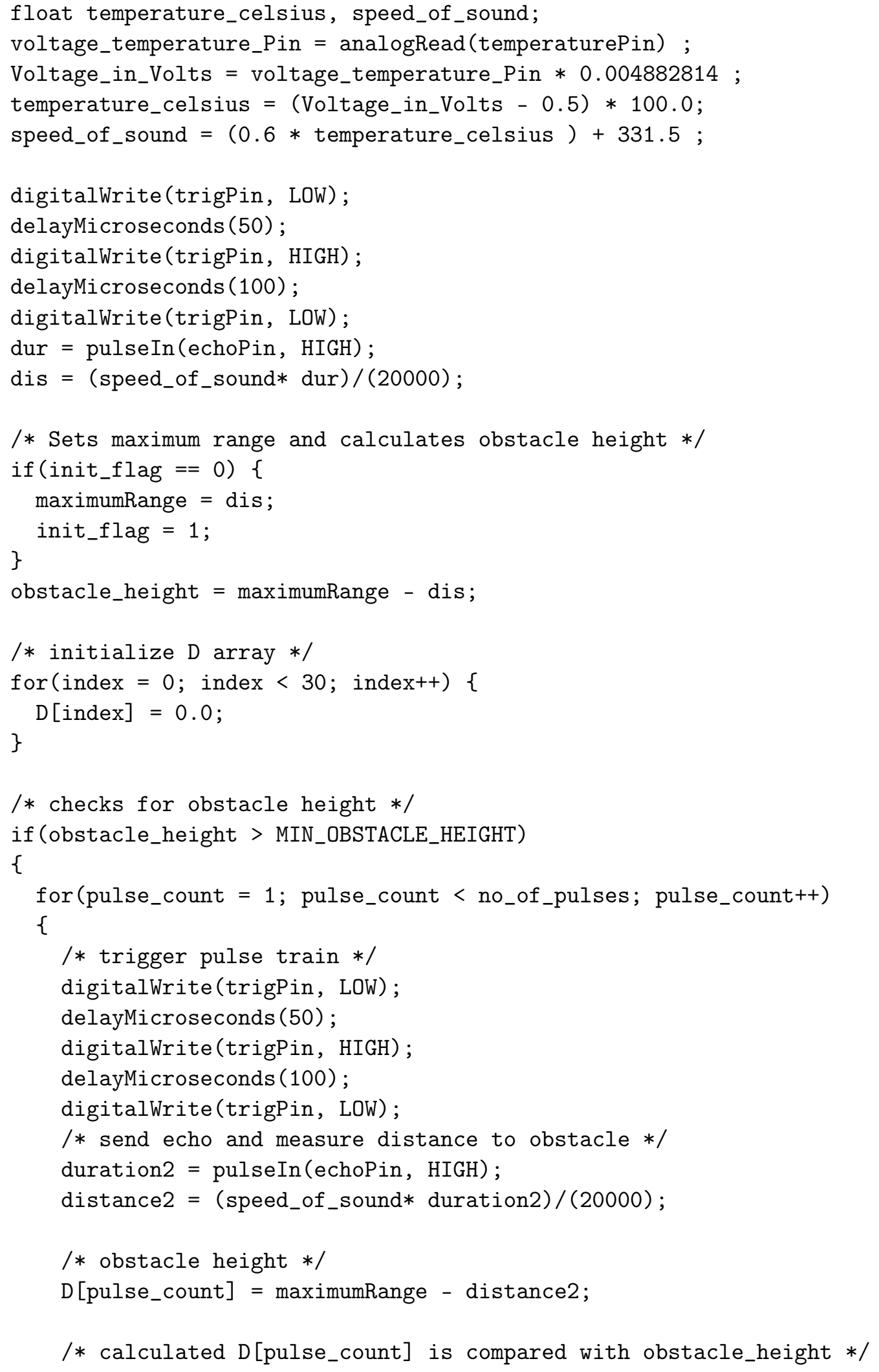




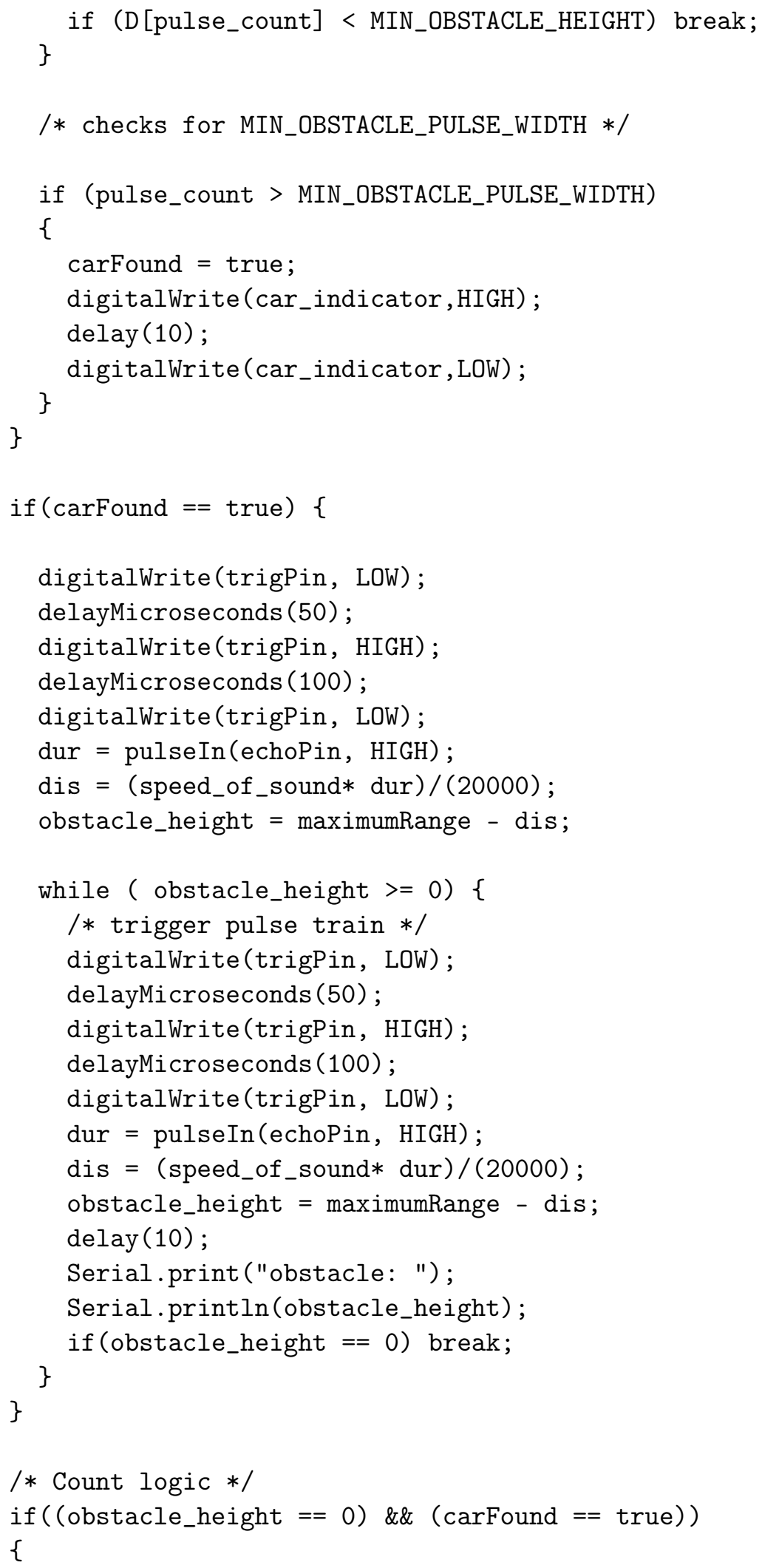




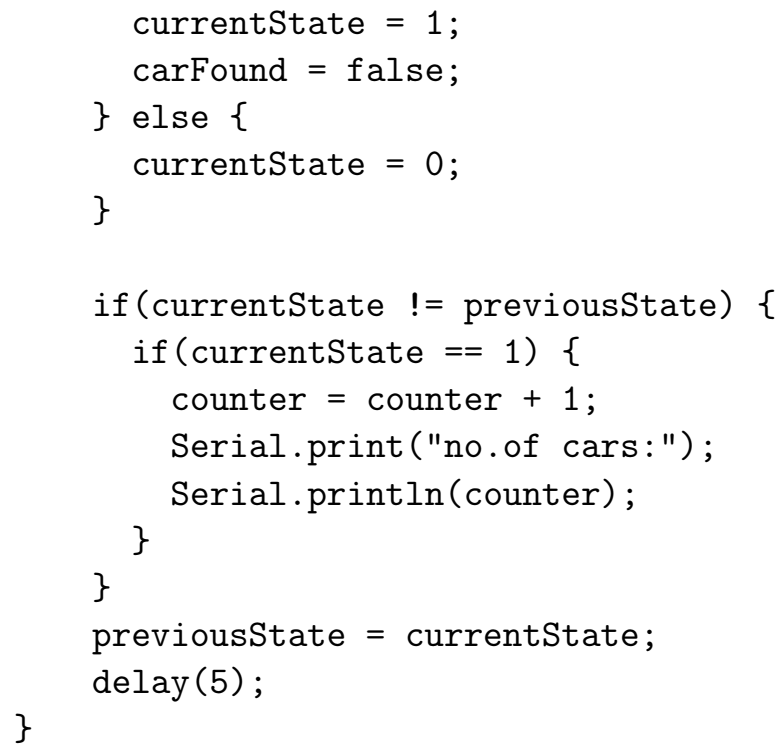




\section{APPENDIX B: ARDUINO COPYRIGHT NOTICE}

Figure 3.6 is an Arduino prototype board and its copyright permission is given below.

\section{Copyright Notice}

Editorial contents of the arduino.cc website, such as texts and photos, are released as Creative Commons Attribution ShareAlike 3.0.

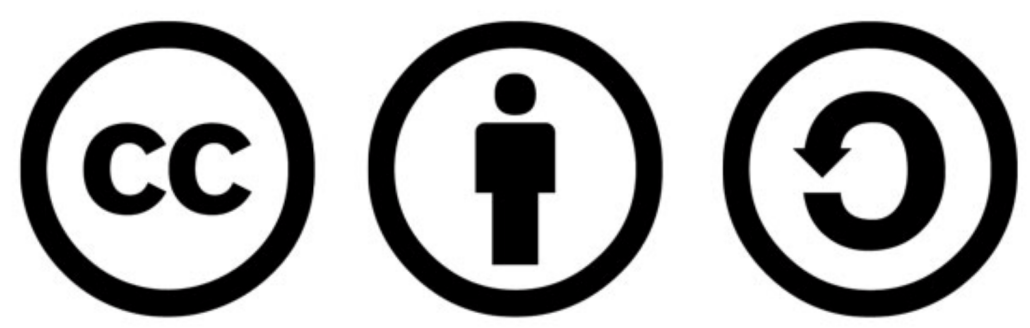

This means you can use them on your own derived works, in part or completely, as long as you also adopt the same license. You find the complete text of the license here (http://creativecommons.org/licenses/by-sa/3.0/legalcode). 


\section{ABOUT THE AUTHOR}

Omkar Dokur completed his Bachelors of Technology in Electronics and Communications Engineering from G. Pulla Reddy Engineering College, India in 2013. He then joined department of Electrical Engineering at University of South Florida, Tampa for a Master's degree. During his master studies, he worked on several research projects for Center for Urban Transportation and Research. 